\title{
Ether Link Cleavage Is the Major Pathway of Iodothyronine Metabolism in the Phagocytosing Human Leukocyte and also Occurs In Vivo in the Rat
}

\author{
Albert G. Burger, Dennis Engler, Ulrich Buergi, Michael Weissel, and \\ Gertraud Steiger, Thyroid Research Unit, Division of Endocrinology, \\ Department of Medicine, University of Geneva, Switzerland
}

SIDNEy H. InGBaR, Thorndike Laboratory of the Beth Israel Hospital, Department of Medicine, Harvard Medical School, Boston, Massachusetts 02215

Richard E. Rosin and Bernard M. Babior, Hematology Service, New England Medical Center Hospital, and the Department of Medicine, Tufts University School of Medicine, Boston, Massachusetts 02111

\begin{abstract}
A BSTRACT These studies were performed to test the hypothesis that ether link cleavage (ELC) is an important pathway for the metabolism of thyroxine $\left(\mathrm{T}_{4}\right)$ in the phagocytosing human leukocyte. When tyrosyl ring-labeled $\left[{ }^{125} \mathrm{I}\right] \mathrm{T}_{4}\left(\left[\mathrm{Tyr}^{125} \mathrm{I}\right] \mathrm{T}_{4}\right)$ was incubated with phagocytosing leukocytes, $50 \%$ of the degraded label was converted into $\left[{ }^{125} I\right] 3,5$-diiodotyrosine ([ $\left.\left.{ }^{125} \mathrm{I}\right] \mathrm{DIT}\right)$. Of the remaining $\left[\mathrm{T}_{\mathrm{yr}}{ }^{125}{ }^{12}\right] \mathrm{T}_{4}$ that was degraded, two-thirds was recovered as $\left[{ }^{125} \mathrm{I}\right]-$ nonextractable iodine $\left.\left({ }^{125} \mathrm{I}\right] \mathrm{NEI}\right)$, and one-third as $\left[{ }^{125}\right.$ I]iodide. The production of [ ${ }^{125}$ I]DIT was not observed when phenolic ring-labeled $\left[{ }^{125} \mathrm{I}\right] \mathrm{T}_{4}$ ([Phen $\left.{ }^{125} \mathrm{I}\right] \mathrm{T}_{4}$ ) was used, although $\left[{ }^{125} \mathrm{I}\right] \mathrm{NEI}$ and $\left[{ }^{[25} \mathrm{I}\right]$ iodide were produced. None of these iodinated compounds were formed in leukocytes that were not carrying out phagocytosis.

The fraction of $T_{4}$ degraded by ELC was decreased by the addition of unlabeled $T_{4}$ and by preheating the leukocytes, findings which suggested that the process was enzymic in nature. ELC was enhanced by the catalase inhibitor aminotriazole, and was inhibited by the peroxidase inhibitor propylthiouracil, suggesting that the enzyme is a peroxidase and that hydrogen peroxide $\left(\mathrm{H}_{2} \mathrm{O}_{2}\right)$ is a necessary cofactor in the reaction.
\end{abstract}

\footnotetext{
These studies have been presented, in part at the $62 \mathrm{nd}$ Annual Meeting of the Endocrine Society, Wash., DC, 1820 June 1980, and have appeared in abstract form (1977. Clin. Res. 25: 291. (Abstr.)

Received for publication 3 September 1982 and in revised form 3 December 1982.
}

To test this hypothesis, studies were performed in several inherited leukocytic disorders. ELC was not observed in the leukocytes of patients with chronic granulomatous disease, in which the respiratory burst that accompanies phagocytosis is absent. ELC was normal in the leukocytes of two subjects homozygous for Swisstype acatalasemia, and aminotriazole enhanced ELC in these cells to an extent not significantly different from that observed in normal cells. ELC was normal in the leukocytes of a patient with myeloperoxidase deficiency, but could be induced by the incubation of [Tyr $\left.{ }^{125} \mathrm{I}\right] \mathrm{T}_{4}$ with $\mathrm{H}_{2} \mathrm{O}_{2}$ and horseradish peroxidase in the absence of leukocytes.

The in vivo occurrence of ELC in the rat was confirmed by demonstrating the appearance of [ $\left.{ }^{125} \mathrm{I}\right] \mathrm{DIT}$ in serum from parenterally injected $\left.{ }^{125} \mathrm{I}\right] 3,5$-diiodothyronine, but no ${ }^{125}$ I]DIT was produced when $\left[{ }^{125} \mathrm{I}\right] 3^{\prime}, 5^{\prime}$-diiodothyronine was administered.

From these findings we conclude the following: $(a)$ ELC is the major pathway for the degradation of $T_{4}$ during leukocyte phagocytosis, and accounts for 50\% of the disposal of this iodothyronine; $(b)$ the NEI and iodide formed by phagocytosing cells are derived from the degradation of the phenolic and tyrosyl rings of $T_{4}$, although ELC per se accounts for only a small fraction of these iodinated products; $(c)$ the process by which ELC occurs is enzymic in nature, and its occurrence requires the presence of the respiratory burst that accompanies phagocytosis; $(d)$ the enzyme responsible for ELC is likely to be a peroxidase, although a clear role for myeloperoxidase as the candidate en- 
zyme remains to be established; $(e)$ iodothyronines are also degraded by ELC in vivo, and the quantitative importance of this pathway in various pathophysiological states requires further investigation.

\section{INTRODUCTION}

It has been appreciated for more than a quarter of a century that the metabolism of thyroxine $\left(T_{4}\right)^{\prime}$ in man is accelerated during acute and chronic systemic illnesses $(1,2)$. This phenomenon, which has been most noticeable in patients with bacterial pulmonary infections (3), is not an invariable accompaniment of illness $(4,5)$, and is not well correlated with alterations in the extracellular binding of the hormone $(3,6)$. The acceleration of $T_{4}$ turnover cannot be accounted for by an increase in $\mathrm{T}_{4}$ disposal by monodeiodination. This pathway is normally responsible for degrading $>70 \%$ of the $T_{4}$ produced $(7,8)$, but in acute and chronic nonthyroidal illnesses, $T_{4} 5^{\prime}$-monodeiodination leading to the generation of triiodothyronine $\left(T_{3}\right)$ is reduced, and $T_{4} 5$-monodeiodination leading to the formation of reverse $\mathrm{T}_{3},\left(\mathrm{rT}_{3}\right)$ is normal or only slightly increased $(9,10)$. These observations therefore suggest that yet another pathway of $T_{4}$ degradation assumes increased importance under these circumstances.

When $T_{4}$, labeled with radioiodine in the tyrosyl ring, is incubated in vitro with rat liver extracts, radiolabeled 3,5-diiodotyrosine (DIT) is formed as a product of the reaction (11-13). These findings demonstrate that extrathyroidal tissues, such as the liver, are capable of degrading $T_{4}$ by disrupting the diphenylether bond linking the tyrosyl and phenolic rings of the molecule, a process termed ether link cleavage. Phagocytosing human leukocytes are also capable of degrading thyroid hormones in vitro, but the mechanism of this degradation has not been fully elucidated, since all the previous studies have used $T_{4}$ labeled with radioiodine in the phenolic ring (14-18).

In the studies reported below, we have investigated the metabolism, by human leukocytes, of $\mathrm{T}_{4}$ labeled with radioiodine in the tyrosyl ring. We demonstrate that ether link cleavage is the major pathway for the metabolism of $T_{4}$ in the phagocytosing leukocyte. Detailed experiments have been performed in several in-

\footnotetext{
' Abbreviations used in this paper: 8-ANS, 8-anilinonaphthalene-1-sulfonic acid; DIHPPA, 3,5-diiodo-4-hydroxyphenylpyruvic acid; DIT, 3,5-diiodotyrosine; ELC, ether link cleavage; $\mathrm{H}_{2} \mathrm{O}_{2}$, hydrogen peroxide; $\mathrm{HRP}$, horseradish peroxidase; KRP, Krebs Ringer phosphate buffer; KRPG, KRP containing $5 \mathrm{mM}$ glucose; MIT, 3-monoiodotyrosine MPO, myeloperoxidase; NEI, nonextractable iodine; $\mathrm{O}_{2}^{-}$, superoxide; $P T U$, propylthiouracil; $\mathrm{rT}_{3}$, reverse $\mathrm{T}_{3}, 3,3^{\prime} 5^{\prime}$-triiodothyronine; $3,5-\mathrm{T}_{2}, 3,5$-diiodothyronine; $3^{\prime}, 5^{\prime}-\mathrm{T}_{2}, 3^{\prime}, 5^{\prime}$-diiodothyronine; $T_{3}, 3,5,3^{\prime}$-triiodothyronine; $T_{4}$, thyroxine.
}

herited leukocytic disorders that suggest the involvement of a peroxidase enzyme and hydrogen peroxide $\left(\mathrm{H}_{2} \mathrm{O}_{2}\right)$ in the process. In addition, data are presented which demonstrate that ELC is an active pathway of iodothyronine metabolism in the living rat. Some of these findings have been presented in abstract form (19).

\section{METHODS}

3-Amino-1,2,4-triazole, L-3,5-DIT, methimazole, and 6-propylthiouracil (PTU) were purchased from Fluka, Buchs, Switzerland; chloramine-T was obtained from Merck, Darmstadt, West Germany and $\mathrm{Na}^{125} \mathrm{I}$ and $\mathrm{Na}^{131} \mathrm{I}$ were obtained from Würenlingen, Switzerland. 3,3',5'-Triiodothyronine ( $\mathrm{rT}_{3}$ ) and 3,5-diiodo-4-hydroxyphenylpyruvic acid (DIHPPA) were generously provided by Dr. Hans Cahnmann, National Institutes of Health, Bethesda, MD. L-T 4 , 3,5,3'-triiodothyronine $\left(\mathrm{T}_{3}\right)$ and zymosan were obtained from Sigma Chemical Co., St. Louis, MO. Sephadex G-25 and LH-20 were obtained from Pharmacia, Uppsala, Sweden and Aminex $50 \mathrm{~W}-\times 4$, sodium form, particle size $30-35 \mu \mathrm{m}$ was purchased from Bio-Rad Laboratories, Richmond, CA.

Preparation of radioactive compounds. Chloramine-T was used to label DIT and the phenolic ring of the iodothyronines $(20)$, and the specific activity of these labeled compounds ranged between 100 and $200 \mu \mathrm{Ci} / \mu \mathrm{g}$.

To prepare $\mathrm{T}_{4}$ randomly labeled with ${ }^{125} \mathrm{I}$ in the phenolic and tyrosyl rings, $1 \mathrm{mCi}$ of $\mathrm{Na}{ }^{125} \mathrm{I}$ was injected subcutaneously into a male rat and the animal was killed by ether anesthesia $24 \mathrm{~h}$ later. The thyroid was removed, digested with pronase, and the randomly labeled $\left[{ }^{125} I\right] \mathrm{T}_{4}$ was extracted into acidified butanol.

$3,5\left[^{125} \mathrm{I}\right] \mathrm{T}_{4}$ was synthesized by the method of Sorimachi and Cahnmann (21), and the following is a description of the procedure as used in this laboratory. $6.4 \mathrm{mg}$ of DIHPPA was dissolved in $150 \mu \mathrm{l}$ acetone and added to $6 \mathrm{mCi}\left[{ }^{125} \mathrm{I}\right] \mathrm{DIT}$ in $0.5 \mathrm{ml} 0.2 \mathrm{M}$ borate-propylene glycol buffer, $\mathrm{pH} 6.8$ (7:1, $\mathrm{vol} / \mathrm{vol}$ ). The mixture was kept at $0^{\circ} \mathrm{C}$ and was bubbled with oxygen for $3 \mathrm{~h}$. During this time, tyrosyl ring-labeled $\left[{ }^{125} \mathrm{I}\right] \mathrm{T}_{4}$ was formed. The $\left[\right.$ Tyr $\left.{ }^{125} \mathrm{I}\right] \mathrm{T}_{4}$ was then separated from [125I]DIT and DIHPPA by cation exchange chromatography on an Aminex $50 \mathrm{~W}-\times 4$ column. The column was prepared in a $2-\mathrm{ml}$ disposable syringe and equilibrated with $2 \mathrm{~N}$ acetic acid. The radioactive products were applied to the column and acidified with $2 \mathrm{~N}$ acetic acid. DIHPPA and its oxidation products were eluted first with $5 \mathrm{ml}$ acetone/ $2 \mathrm{~N}$ acetic acid (1:1, vol/vol); [ $\left.{ }^{125} \mathrm{I}\right] \mathrm{DIT}$ was then eluted with $5 \mathrm{ml} \mathrm{H}_{2} \mathrm{O}$ and [Tyr $\left.{ }^{125} \mathrm{I}\right] \mathrm{T}_{4}$ was eluted with $3 \mathrm{ml}$ of ethanol $/ 2 \mathrm{~N} \mathrm{NH}_{3}(7: 3$, $\mathrm{vol} / \mathrm{vol})$. The eluted [ $\mathrm{Tyr}^{125} \mathrm{I}_{\mathrm{I}} \mathrm{T}_{4}$ was dried under nitrogen at $50^{\circ} \mathrm{C}$, and then chromatographed by methods described by Sorimachi and Ui (22). The purity of the $\left[\mathrm{Tyr}^{125} \mathrm{I}\right] \mathrm{T}_{4}$ was determined by thin-layer chromatography (Merck No. 254 silica gel, and isopropanol, $n$-butyl acetate, $\mathrm{H}_{2} \mathrm{O}, 25 \%$ ammonia as the solvent system 50:30:15:5), and by immunoprecipitation of the label with a $T_{4}$ antiserum.

$\left[{ }^{125} I\right] 3,5-D i i o d o t h y r o n i n e ~\left(\left[{ }^{125} I\right] 3,5-T_{2}\right)$ was synthesized according to the method of Sorimachi and Cahnmann (21), and was purified by cation exchange chromatography on an Aminex $50 \mathrm{~W}-\times 4$ column, followed by descending paper chromatography on Whatman 3MM paper (Whatman, Inc., Clifton, NJ) using hexane/tertiary amyl alcohol/2 $\mathrm{N}$ ammonia (1:5:6) as the solvent (23).

Preparation and incubation of leukocytes. Human leukocytes were isolated by the method described by Pincus 
and Klebanoff (24). The preparation contained lymphocytes, monocytes, and granulocytes, and their viability was determined by trypan blue exclusion. Incubations were performed in $10-\mathrm{ml}$ polypropylene centrifuge tubes at $37^{\circ} \mathrm{C}$. The radioactive labels used were generally $\left[\mathrm{Tyr}^{125} \mathrm{I}^{2} \mathrm{~T}_{4}\right.$ and $\left[{ }^{131} \mathrm{I}\right] \mathrm{DIT}$ These were dissolved in $0.5 \mathrm{ml}$ Krebs Ringer phosphate buffer containing $5 \mathrm{mM}$ glucose (KRPG) and $0.05 \%$ bovine serum albumin. The zymosan was opsonized by incubating $5 \mathrm{mg}$ with $1 \mathrm{ml}$ of serum for $30 \mathrm{~min}$ at $37^{\circ} \mathrm{C}$. The mixture was centrifuged $(12,000 \mathrm{rpm})$ and washed twice with Krebs Ringer phosphate buffer. $200 \mu \mathrm{l}$ opsonized zymosan was added $(5 \mathrm{mg} / \mathrm{ml})$, and the reaction was started by adding $200 \mu$ l KRPG containing $10^{7}$ leukocytes. Two types of control incubations were used. In the first, zymosan was omitted, and $200 \mu \mathrm{l}$ KRPG was merely added. In the second, the leukocytes were boiled before their addition to the reaction tubes. When the effects of $\mathrm{H}_{2} \mathrm{O}_{2}$, aminotriazole, methimazole, or horseradish peroxidase (HRP) were to be studied, these agents were added in $20 \mu \mathrm{l} \mathrm{KRPG}$ before the addition of zymosan or the leukocytes. The reaction was stopped by adding $3 \mathrm{vol}$ of ice-cold ethanol containing $0.1 \%$ PTU and shaking the tube gently. The incubation mixture was then centrifuged $(6,000 \mathrm{~g}, 15 \mathrm{~min})$, and the supernatant fluids were collected. The pellet was washed once with $1 \mathrm{ml}$ of ethanol and counted in a well-type gamma scintillation counter.

Chromatography. Identification of the products of the reaction was performed by gel filtration, cation exchange, and paper chromatography as described below.

Gel adsorption chromatography was performed with Sephadex G-25. The columns (bed volume $13 \mathrm{ml}, 8-\mathrm{mm}$ diam) were equilibrated with $0.05 \mathrm{~N}$ sodium acetate buffer, $\mathrm{pH}$ 4.8. The dried supernatant extracts were reconstituted in 0.2 $\mathrm{N}$ acetic acid, and an aliquot of $200 \mu \mathrm{l}$ was applied to the column. On this column, iodide eluted according to its molecular weight. The tyrosines and thyronines were adsorbed by the gel, and their elution profile was a function of their relative strength of adsorption. Using the sodium acetate buffer for elution, 60-drop fractions were collected. Iodide was eluted in fractions 7 to 12,3 -monoiodotyrosine (MIT) was eluted in fractions 13 to 16 , and DIT was eluted in fractions 16 to 24 . The iodothyronines were eluted in an alkaline $\mathrm{pH}$ by using ethanol/2 $\mathrm{N} \mathrm{NH}_{3}(7: 3, \mathrm{vol} / \mathrm{vol})$ as the eluting agent. This method of chromatography did not separate $T_{3}, \mathrm{rT}_{3}$, and the diiodothyronines from $T_{4}$

Cation exchange chromatography was performed on columns of Aminex 50W-X4 as described by Sorimachi and Ui (22), and descending paper chromatography was performed as described above.

For most experiments, the products of leukocyte phagocytosis were analyzed by a simplified procedure. This consisted of passing the reaction products through a mixture of Sephadex LH-20 and Aminex in its acidic form (9:1). This mixture was poured into $2-\mathrm{ml}$ disposable syringes (bed volume $0.75 \mathrm{ml}$ ) and the columns were equilibrated with 0.2 $\mathrm{N}$ acetic acid. $0.5 \mathrm{ml}$ of the ethanolic supernates were added to these columns and acidified with $1 \mathrm{ml} 0.2 \mathrm{~N}$ acetic acid Iodide was eluted with $5 \mathrm{ml} 0.2 \mathrm{~N}$ acetic acid, [ $\left.{ }^{125} \mathrm{I}\right] \mathrm{DIT}$ was eluted with $12.5 \mathrm{ml} 0.2 \mathrm{~N}$ ammonium acetate, $\mathrm{pH} 5$, containing $30 \%$ ethanol, while $\left[{ }^{125} \mathrm{I}\right] \mathrm{T}_{4}$ was retained on the column. The radioactivity on the columns was directly measured in a well-type gamma scintillation counter.

Immunoprecipitation of $\left[{ }^{131} \mathrm{I}\right] \mathrm{T}_{3}$ and $\left[{ }^{125} \mathrm{I}\right] T_{3}$. This procedure was used to process the supernatant extracts from the experiments in which the quantitative importance of leukocyte $5^{\prime}$-monodeiodination was assessed. In these experiments, $\left[{ }^{131} \mathrm{I}\right] \mathrm{T}_{4}$ and $\left[{ }^{125} \mathrm{I}\right] \mathrm{T}_{3}$ were incubated with leukocytes as described above. The $\left.{ }^{125} \mathrm{I}\right] \mathrm{T}_{3}$ was added as an internal standard to monitor the degradation and losses of $T_{3}$ during the experiment. The reaction was terminated by the addition of $3 \mathrm{vol}$ of ethanol containing $0.1 \%$ PTU. $1 \mathrm{ml}$ of the supernatant extract was then incubated with $4 \mathrm{ml} 0.05 \mathrm{M}$ phosphate buffer $\mathrm{pH} 7.4$ at $4^{\circ} \mathrm{C}$, and $\mathrm{l} \mu \mathrm{l}$ of a rabbit $\mathrm{T}_{3}$ antiserum and $1 \mu \mathrm{l}$ of normal rabbit serum were then added. The tubes were incubated for $24 \mathrm{~h}$ at $4^{\circ} \mathrm{C}$, after which $20 \mu \mathrm{l}$ of goat anti-rabbit gamma globulin was added to precipitate the antibody-bound hormone. After a further $12 \mathrm{~h}$, the tubes were centrifuged $(5,000 \mathrm{~g}, 10 \mathrm{~min})$, the supernates were aspirated, and the precipitates washed with $1 \mathrm{ml}$ of ice-cold $0.9 \% \mathrm{NaCl} .84 \pm 3.7 \%(n=6)$ of pure labeled $\mathrm{T}_{3}$ was precipitated by this procedure. Since a large quantity of $T_{3}$ antiserum was used, the cross-reactivity with $\mathrm{T}_{4}$ was increased and $9.9 \pm 0.9 \%(n=6)$ of pure $\left[{ }^{131} \mathrm{I}\right] \mathrm{T}_{4}$ was also precipitated. Therefore a further purification step became necessary. The precipitate was dissolved in $0.1 \mathrm{ml} 0.05 \mathrm{~N} \mathrm{NaOH}$, and 600 $\mu \mathrm{g}$ of unlabeled $\mathrm{T}_{4}$ and $\mathrm{T}_{3}$ were then added. The mixture was incubated at $70^{\circ} \mathrm{C}$ for $10 \mathrm{~min}$, and the solution was subjected to descending paper chromatography as described above. The $T_{4}$ and $T_{3}$ areas were identified with the ninhydrin reagent, and the areas were cut out and counted in a gamma counter. From these results, the percentage of $\left[{ }^{131} \mathrm{I}\right] \mathrm{T}_{4}$ converted to $\left[{ }^{131} \mathrm{I}\right] \mathrm{T}_{3}$ was obtained. The values of $\left[{ }^{131} I\right] T_{3}$ obtained during the incubation were corrected for the losses incurred during the extraction procedures by correcting the measured $\left[{ }^{131} \mathrm{I}\right] \mathrm{T}_{3}$ values with those based on the behavior of $\left[{ }^{125} I\right] T_{3}$. An estimate of the losses of $\left[{ }^{131} I\right] T_{3}$ due solely to the extraction methods was provided by examining the samples obtained at time zero, since it could be assumed that the amount of $\left.{ }^{125} \mathrm{I}\right] \mathrm{T}_{3}$ degraded in these tubes was negligible. Although this mode of correction only provided an approximation of the losses of $\left[{ }^{131} \mathrm{I}\right] \mathrm{T}_{3}$ due to degradation, the degradation of $\left[{ }^{131} \mathrm{I}\right] \mathrm{T}_{3}$ was not excessively rapid and was similar to that of $\left[{ }^{131}{ }^{1}\right] \mathrm{T}_{4}$ (Results). The application of this correction factor changed the measured value of $\mathrm{T}_{4} 5^{\prime}$-monodeiodination by $0.1-0.2 \%$, and had it not been applied, the estimated amount of $\mathrm{T}_{4}$ degraded by this route would have been even lower.

In vivo studies. To demonstrate ELC in vivo, 25 male ZVIC rats (250-300 g, Universitäts Tierzuchtinstitut, Zürich) were injected subcutaneously with $18 \mu \mathrm{Ci}\left[{ }^{125} \mathrm{I}\right] 3,5-\mathrm{T}_{2}$ and 0.9 $\mu \mathrm{Ci}\left[{ }^{131} \mathrm{I}\right] \mathrm{DIT}$ in $0.2 \mathrm{ml}$ of $0.9 \% \mathrm{NaCl}$ containing $5 \%$ rat serum. To ensure an accurate assessment of the amount of radioactivity given, the syringes containing the solution were weighed before and after the injection. The thyroid uptake of radioactivity was minimized by administering potassium iodide $(10 \mathrm{mg}$ in $0.2 \mathrm{ml} 0.9 \% \mathrm{NaCl}$ i.p. and $0.5 \mathrm{mg} / \mathrm{ml}$ in the drinking water) for $2 \mathrm{~d}$ before the experiment. The animals were killed in groups of five at $5,20,60,120$, and 240 min. Twice the usual dose of radioactivity was used for the 60 and $240 \mathrm{~min}$ time points to ensure that adequate amounts of radioactivity would be found in the serum.

In a control experiment, 16 rats were injected with 18 $\mu \mathrm{Ci}\left[{ }^{125} \mathrm{I}\right] 3^{\prime}, 5^{\prime}-\mathrm{T}_{2}$ and $0.9 \mu \mathrm{Ci}\left[{ }^{131} \mathrm{I}\right] \mathrm{DIT}$ subcutaneously, and were killed in groups of four at $30,90,165$, and $240 \mathrm{~min}$ after the injection.

Analysis of serum radioactivity obtained from the in vivo experiments. The $\left[{ }^{125} \mathrm{I}\right] 3,5-\mathrm{T}_{2},\left[{ }^{125} \mathrm{I}\right] \mathrm{DIT}$, and [ $\left.{ }^{131} \mathrm{I}\right] \mathrm{DIT} \mathrm{ra}-$ dioactivities were initially isolated by immunoprecipitation.

Immunoprecipitation of $\left[{ }^{125} \mathrm{I}\right] 3,5-\mathrm{T}_{2}$ was achieved by incubating $200 \mu \mathrm{l}$ of rat serum with $1 \mathrm{mg}$ sodium salicylate and $3,5-\mathrm{T}_{2}$ antiserum. The tubes were incubated for $4 \mathrm{~h}$ at $37^{\circ} \mathrm{C}$ and for $36 \mathrm{~h}$ at $4^{\circ} \mathrm{C}$; the bound $\left[{ }^{125} \mathrm{I}\right] 3,5-\mathrm{T}_{2}$ was precipitated by adding $20 \mu \mathrm{l}$ of anti-rabbit gamma globulin, and the incubation was continued for a further $12 \mathrm{~h}$, after 
which the tubes were centrifuged $(5,000 \mathrm{~g}, 10 \mathrm{~min})$. The precipitate was washed with $1 \mathrm{ml} 0.9 \% \mathrm{NaCl}$ and counted. At each time point, the nonspecific binding was also evaluated by substituting $2 \mu \mathrm{l}$ of normal rabbit serum for the $3,5-\mathrm{T}_{2}$ antiserum. To provide an estimate of recovery, parallel incubations were performed in which pure $\left[{ }^{125} \mathrm{I}\right] 3,5-\mathrm{T}_{2}$ was added to rat serum and handled as above. The percent $\left[{ }^{125} \mathrm{I}\right] 3,5-\mathrm{T}_{2}$ precipitated in the recovery tubes ranged between 80 and $85 \%$, and the values obtained in the experimental samples were corrected for this recovery.

$\left[{ }^{125}\right.$ I]DIT and $\left[{ }^{131} I\right] D I T$ were immunoprecipitated by incubating $2 \mathrm{ml}$ rat serum with $2.5 \mathrm{mg} 8$-anilinonaphthalene$\mathrm{l}$-sulfonic acid (ANS) in $100 \mu \mathrm{l} 0.9 \% \mathrm{NaCl}$ and $10 \mu \mathrm{l}$ of a rabbit DIT antiserum (No. 134, 1979). At each point in time nonspecific binding was determined by substituting an equivalent volume of normal rabbit serum for the antiserum The incubation conditions were identical to those described above for the immunoprecipitation of $\left[{ }^{125} \mathrm{I}\right] 3,5-\mathrm{T}_{2}$. To precipitate the bound $\left[{ }^{125}\right.$ I]DIT and $\left[{ }^{131}\right.$ I]DIT, $60 \mu$ of goat antirabbit gamma globulin was required. This resulted in the appearance of a large precipitate. To facilitate its chromatographic analysis, the precipitate was digested with pronase $(2.5 \mathrm{mg}$ in $100 \mu \mathrm{l} 0.05 \mathrm{M}$ phosphate buffer, $\mathrm{pH} 7.0$ ). The samples were incubated for $12 \mathrm{~h}$ at $37^{\circ} \mathrm{C}$, and the enzyme was then inactivated by alkalinization $(100 \mu l 0.1 \mathrm{~N}$ $\mathrm{NaOH})$ and acidification $(20 \mu \mathrm{l} 1 \mathrm{~N} \mathrm{HCl}) .900 \mu \mathrm{l}$ of butanol saturated with $2 \mathrm{~N}$ acetic acid was then added to the precipitate, and resulted in the appearance of two phases; the radiolabeled DIT was extracted into the upper phase. The upper phase was collected, the procedure was repeated twice, and the butanol extract was dried under a vacuum. This extract was then redissolved in $200 \mu \mathrm{l} 0.05 \mathrm{M} \mathrm{NaOH}$ containing $1 \mathrm{nmol}$ unlabeled DIT, and was subjected to cat ion exchange chromatography on an Aminex $50 \mathrm{~W}-\times 4 \mathrm{col}-$ umn. After the initial chromatography, the fractions containing [ ${ }^{125}$ I]DIT and $\left[{ }^{131}\right.$ I]DIT were pooled, evaporated to dryness, and rechromatographed. This was done to eliminate iodinated impurities remaining after the first chromatography step. To provide an estimate of recovery, two nonradioactive rat sera were enriched with the injection solution (containing $\left[{ }^{125} \mathrm{I}\right] 3,5-\mathrm{T}_{2}$ and $\left[{ }^{131} \mathrm{I}\right] \mathrm{DIT}$ ) and treated as above From these samples, the recovery of $\left[{ }^{131} I\right] D I T$ was calculated and the amount of $\left[{ }^{125} \mathrm{I}\right] \mathrm{DIT}$ present as a contaminant in the $\left[{ }^{125} \mathrm{I}\right] 3,5-\mathrm{T}_{2}$ solution was measured.

Radioimmunoassay of DIT. In initial experiments, the antiserum used for this radioimmunoassay was kindly supplied by Dr. J. Nelson. Subsequently, experiments were performed with an antiserum generated in this laboratory. This latter antiserum demonstrated a cross-reactivity of $<0.2 \%$ with $\mathrm{T}_{4}, \mathrm{~T}_{3}, \mathrm{rT}_{3}$, and the diiodothyronines. The assay was performed by the addition of the following reagents to the reaction tubes: $(a)$ standards containing 50 to $3,200 \mathrm{fmol}$ unlabeled DIT/tube were added in $200 \mu \mathrm{l} 0.05 \mathrm{M}$ phosphate buffer, pH 7.0. The unknown samples measured in the radioimmunoassay were usually column fractions. The DIT in these samples was initially dissolved in $0.05 \mathrm{~N} \mathrm{NaOH}$ and subsequently diluted in $0.05 \mathrm{M}$ phosphate buffer and added as a $200 \mu \mathrm{l}$ aliquot; $(b) 0.4 \mu \mathrm{l}$ DIT antiserum in $50 \mu \mathrm{l}$ phosphate buffer; $(c)\left[{ }^{125}\right.$ I]DIT $(10,000 \mathrm{cpm})$ was added in 20 $\mu l$ phosphate buffer. The tubes were incubated for $12 \mathrm{~h}$ at $4^{\circ} \mathrm{C}$, and the antibody-bound hormone was separated from the free hormone by the addition of $1.7 \mathrm{ml} 18 \%$ polyethylene glycol $(6,000-\mathrm{mol} \mathrm{wt})$. After $1 \mathrm{~h}$ at $4^{\circ} \mathrm{C}$, the tubes were centrifuged $(3,000 \mathrm{rpm}, 15 \mathrm{~min})$, the supernates were aspirated and the precipitates were counted.

Statistics. Statistical analysis of the results has been performed using Student's $t$ test for unpaired data (25).

\section{RESULTS}

\section{Chromatographic identification of the products of $T_{4}$ metabolism in phagocytosing leukocytes}

Three independent methods were used to verify the production of DIT from $\mathrm{T}_{4}$ during leukocyte phagocytosis. These were gel filtration, cation exchange, and paper chromatography.

Gel filtration chromatography. In the initial experiments, incubations were performed with $\mathrm{T}_{4}$ randomly labeled with ${ }^{125} \mathrm{I}$ in both the phenolic and tyrosyl rings. Subsequently, $\left[\right.$ Tyr $\left.{ }^{125} \mathrm{I}\right] \mathrm{T}_{4}$ was used in all the experiments. When randomly labeled $\left[{ }^{125} \mathrm{I}\right] \mathrm{T}_{4}$ was incubated with nonactivated leukocytes, it was not degraded. This conclusion is based on the observation that extracts of the incubation medium, when analyzed by Sephadex G-25 column chromatography, contained only $\left[{ }^{125} \mathrm{I}\right] \mathrm{T}_{4}$ (Fig. 1). The small amount of ${ }^{125} \mathrm{I}$ seen represents an impurity in the starting material.

To compare the products of metabolism of the phenolic and tyrosyl rings of $\mathrm{T}_{4}$, randomly labeled $\left[{ }^{125} \mathrm{I}\right] \mathrm{T}_{4}$ and $\left[\right.$ Phen ${ }^{131} \mathrm{I}^{1} \mathrm{~T}_{4}$ were incubated with zymosan-activated leukocytes (Fig. 1). The ${ }^{125} \mathrm{I}$ and ${ }^{131}$ I radioactivity in the $\mathrm{T}_{4}$ area were identical, but were decreased compared with the $T_{4}$ radioactivity remaining in specimens incubated without zymosan. This demonstrated that both $\left[{ }^{131} \mathrm{I}\right] \mathrm{T}_{4}$ and $\left[{ }^{125} \mathrm{I}\right] \mathrm{T}_{4}$ had been degraded. How ever, the products of degradation differed in that a peak of radioactivity was generated by the metabolism of the randomly labeled $\left[{ }^{125} \mathrm{I}\right] \mathrm{T}_{4}$ that was not generated from [Phen $\left.{ }^{131} \mathrm{I}\right] \mathrm{T}_{4}$. This peak, derived from the iodinated tyrosyl ring, coincided with the elution pattern of $\left[{ }^{125} \mathrm{I}\right] \mathrm{DIT}$, and demonstrated that cleavage of the ether link of $\mathrm{T}_{4}$ had occurred.

Cation exchange chromatography. $\quad \mathrm{As} \mathrm{T}_{3}$ and $\mathrm{rT}_{3}$ are not separated from $\mathrm{T}_{4}$ by Sephadex gel filtration, the products of the incubation were also analyzed by cation exchange chromatography. This technique was also used to provide an independent proof of the formation of DIT from $\mathrm{T}_{4}$ by phagocytosing leukocytes. Zymosan-activated leukocytes were incubated with [Tyr $\left.{ }^{125} \mathrm{I}\right] \mathrm{T}_{4}$ and $\left[{ }^{131} \mathrm{I}\right] \mathrm{DIT}$ and the supernatant extracts obtained at $5,15,30$, and $60 \mathrm{~min}$ were applied to an Aminex 50W- $\times 4$ column (Fig. 2). At each time point, three major peaks were identified, which corresponded to the elution pattern of iodide, DIT, and $\mathrm{T}_{4}$.

Paper chromatography. The $\left[{ }^{125} \mathrm{I}\right] \mathrm{DIT}$ and $\left[{ }^{125} \mathrm{I}\right] \mathrm{T}_{4}$ fractions obtained by cation exchange chromatography were subjected to descending paper chromatography. On this system, the migration of the labeled compounds coincided with that of unlabeled DIT and $\mathrm{T}_{4}$ 


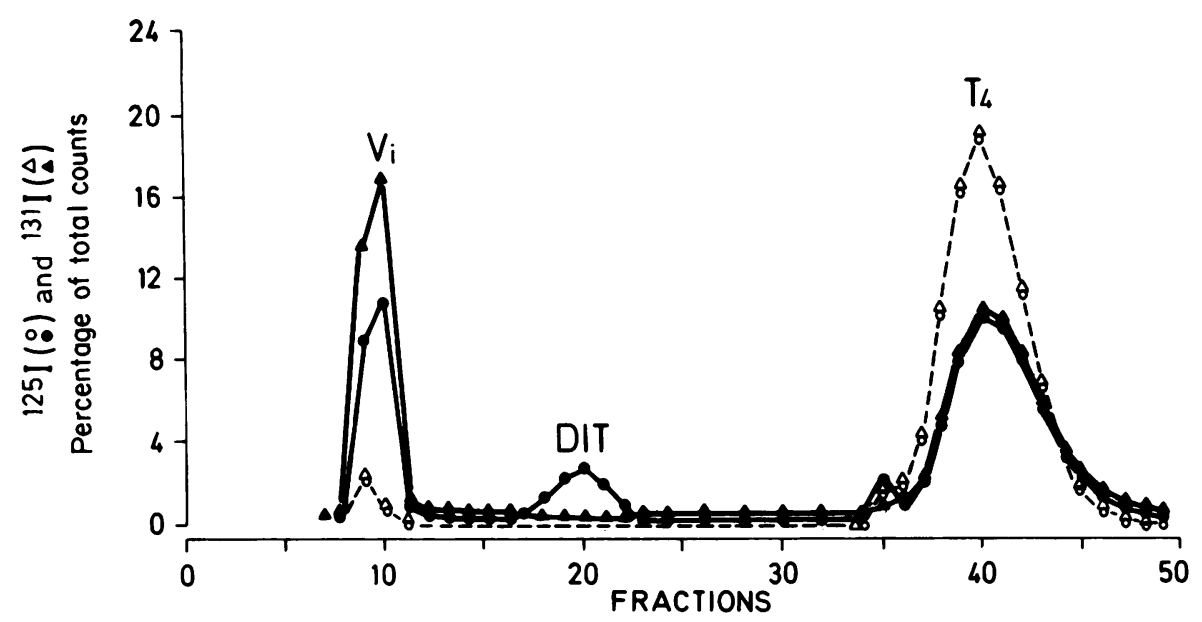

FICURE 1 Gel filtration chromatography of the products of metabolism of randomly labeled $\left[{ }^{125} \mathrm{I}\right] \mathrm{T}_{4}$ and $\left[\right.$ Phen $\left.{ }^{131} \mathrm{I}\right] \mathrm{T}_{4}$ by human leukocytes. The reaction mixture was dissolved in $0.2 \mathrm{~N}$ acetic acid and applied as a $200 \mu \mathrm{l}$ volume to a column of G-25 Sephadex. 60-drop fractions were collected by eluting the column with ammonium acetate, $0.05 \mathrm{M}, \mathrm{pH} 4.8$. After 30 fractions were collected, the elution buffer was changed to $2 \mathrm{~N}$ ammonium hydroxide and ethanol $(7: 3$, $\mathrm{vol} / \mathrm{vol})$. [Phen $\left.{ }^{131} \mathrm{I}\right] \mathrm{T}_{4}$, no zymosan $(\triangle)$; randomly labeled $\left[{ }^{125} \mathrm{I}\right] \mathrm{T}_{4}$, no zymosan $(O) ;\left[\right.$ Phen $\left.{ }^{131} \mathrm{I}\right] \mathrm{T}_{4}$, zymosan added $(\Delta)$; randomly labeled $\left[{ }^{125} \mathrm{I}\right] \mathrm{T}_{4}$, zymosan added $(\bullet)$.

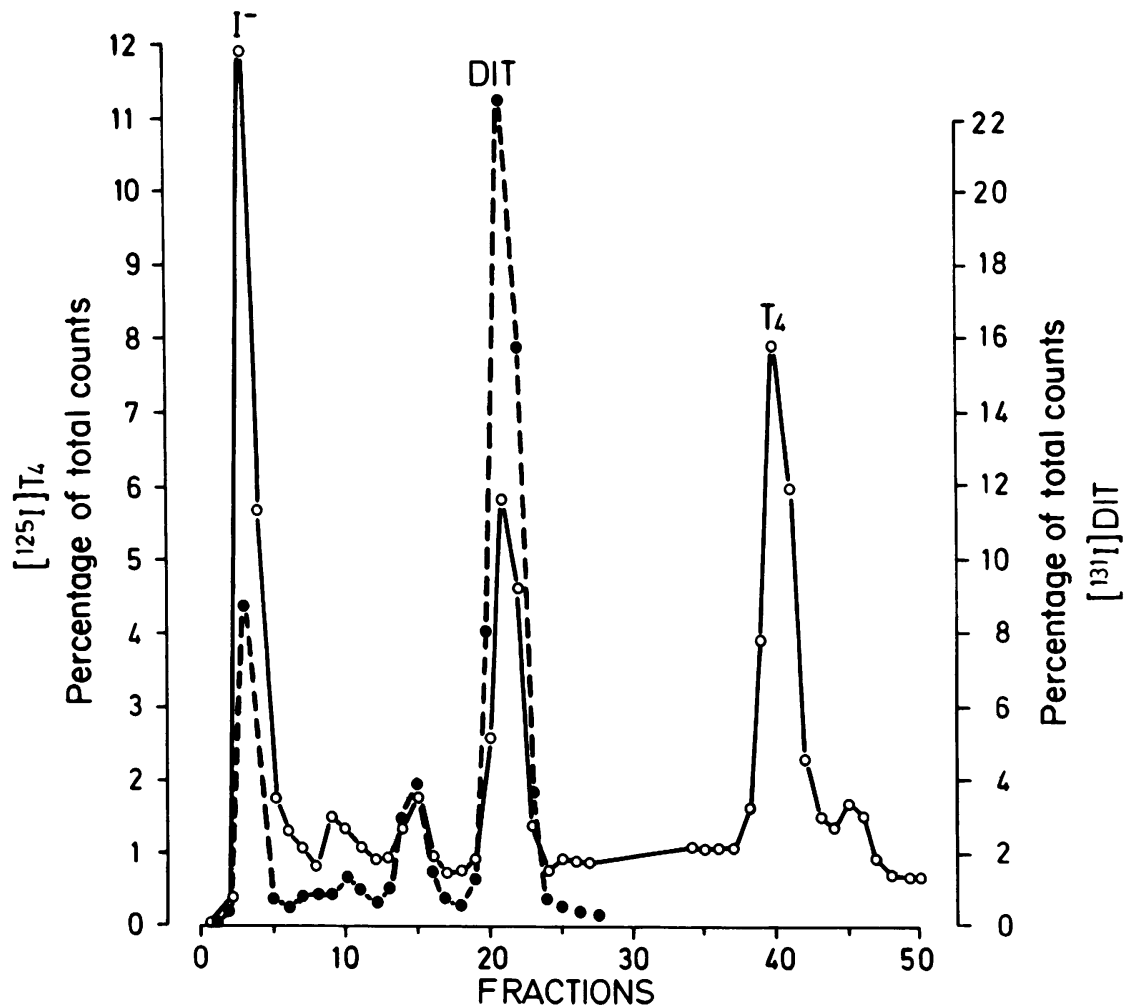

FIGURE 2 Cation exchange chromatography of the products of metabolism of $\left[\right.$ Tyr $\left.{ }^{125} \mathrm{I}\right] \mathrm{T}_{4}$ $(O)$ obtained at $30 \mathrm{~min}$ of incubation. $\left.{ }^{[31} \mathrm{I}\right] \mathrm{DIT}(\bullet)$ was also added to the reaction mixture and used as a marker. The mixture was reconstituted in $0.2 \mathrm{~N}$ acetic acid and applied as a 200 $\mu \mathrm{l}$ volume to an Aminex $50 \mathrm{~W}-\times 4$ column $(10 \times 0.8 \mathrm{~cm})$. The column was eluted with a gradient composed of an equal volume of ammonium acetate $0.04 \mathrm{M}, \mathrm{pH} 4.8 / 100 \%$ ethanol $(7: 3 \mathrm{vol} /$ $\mathrm{vol})$, and ammonium hydroxide $0.75 \mathrm{~N} / 100 \%$ ethanol $(7: 3, \mathrm{vol} / \mathrm{vol})$. On this column, iodide was eluted in fractions 4 to 8 , DIT in fractions 19 to 24 , and $T_{4}$ in fractions 38 to 43 . 
TABLE I

Metabolism of $T_{4}$ and of its Degradation Product, DIT, by Human Leukocytes

\begin{tabular}{|c|c|c|c|c|c|c|}
\hline \multirow[b]{2}{*}{ Zymosan } & & \multicolumn{5}{|c|}{ Incubation time (min) } \\
\hline & & 0 & 5 & 15 & 30 & 60 \\
\hline \multirow[t]{7}{*}{ Present } & {$\left[t y r^{125} \mathrm{ITT}_{4}\right.$} & $93.8 \pm 4.3(6)^{\bullet} \downarrow$ & $87.8 \pm 5.1(18) \S^{\prime \prime}$ & $70.7 \pm 11.8(18) \S \pi$ & $62.5 \pm 11.8$ (17)§ा & $60.1 \pm 13.9(18) \S \pi$ \\
\hline & {$\left[{ }^{125} \mathrm{I}\right] \mathrm{DIT}$} & $2.7 \pm 0.9(6)$ & $5.4 \pm 1.9(10) \S$ & $13.9 \pm 6.0 \quad(10) \S$ & $16.7 \pm 7.2 \quad(10) \S$ & $17.4 \pm 6.3(10) \S \pi$ \\
\hline & {$\left[{ }^{125} \mathrm{I}\right] \mathrm{NEI}$} & $5.0 \pm 0.8(10)$ & $5.5 \pm 1.5(10)^{\circ}$ & $11.4 \pm 3.8 \quad(10) \S$ & $16.5 \pm 3.7 \quad(10) \S$ & $19.1 \pm 4.1 \quad(10) \S \pi$ \\
\hline & ${ }^{125} \mathrm{I}$ & $2.3 \pm 1.7(8)$ & $2.2 \pm 0.8(10)$ & $4.0 \pm 1.1 \quad(10)^{\circ}$ & $8.7 \pm 2.4 \quad(10) \S$ & $9.2 \pm 2.0(10) \S^{\prime \prime}$ \\
\hline & {$\left[{ }^{131} \mathrm{I}\right] \mathrm{DIT}$} & $97.8 \pm 2.1(6)$ & $95.5 \pm 2.4(10)^{\circ \bullet}$ & $89.0 \pm 4.5(10) \S$ & $85.8 \pm 3.9$ (10)§" & $84.9 \pm 5.3(10) \S^{\prime \prime}$ \\
\hline & {$\left[{ }^{131} I\right] N E I$} & $3.7 \pm 1.0$ & $3.3 \pm 0.3(6)$ & $6.2 \pm 1.3(6)^{\circ}$ & $8.2 \pm 1.5 \quad(6) \downarrow t$ & $8.9 \pm 3.0$ \\
\hline & ${ }_{131}^{131} \mathbf{I}$ & $2.1 \pm 2.2(6)$ & $4.9 \pm 1.8(6)^{\bullet \bullet}$ & $8.4 \pm 1.7 \quad(6) \S$ & $9.6 \pm 1.1 \quad(6) \S$ & $9.9 \pm 2.1 \quad(6) \S \pi$ \\
\hline Absent & {$\left[\right.$ tyr $\left.^{125} \mathrm{I}\right] \mathrm{T}_{4}$} & $89.0 \pm 6.0(15)$ & $92.8 \pm 1.5(5)$ & $93.6 \pm 2.1$ & $92.8 \pm 1.3$ & $93.5 \pm 2.3 \quad(10)$ \\
\hline $\begin{array}{l}\text { Present, } \\
\text { boiled cells }\end{array}$ & {$\left[t y r^{125} \mathrm{I}\right] \mathrm{T}_{4}$} & $92.9 \pm 1.8$ & - & - & - & $92.0 \pm 2.7$ \\
\hline
\end{tabular}

- Radioactivity expressed as percentage of total per flask (mean \pm SEM).

$\$$ Numbers in parentheses represents the number of flasks.

$\$ P<0.001$ compared with time 0 .

" $P<0.01$ compared with incubation without zymosan.

I $P<0.001$ compared with incubation without zymosan.

$\because P<0.025$ compared with time 0 .

If $P<0.01$ compared with time 0 .

Combined gel filtration-cation exchange chromatography. The procedures outlined above have demonstrated the production of iodide and DIT from $\mathrm{T}_{4}$ during leukocyte phagocytosis. In the experiments described below, the products of $\mathrm{T}_{4}$ metabolism were analyzed by chromatography on columns containing a mixture of LH-20 and Aminex $50 \mathrm{~W}-\mathrm{X} 4$. In 10 preliminary experiments, the recovery of [ $\left.{ }^{125} \mathrm{I}\right] \mathrm{DIT}$ was $99 \pm 1.5 \%$ and that of $\left[{ }^{125} \mathrm{I}\right] \mathrm{T}_{4}$ was $98 \pm 2 \%$.

\section{Quantitative assessment of the metabolism of $T_{4}$ and of its degradation product DIT during phagocytosis (Table I)}

In these experiments, $\left[\right.$ Tyr $\left.^{125} \mathrm{I}\right] \mathrm{T}_{4}$ was incubated with zymosan-activated leukocytes, and the degradation of DIT was assessed simultaneously by the addition of $\left[{ }^{131} \mathrm{I}\right] \mathrm{DIT}$ to the medium. [ $\mathrm{Tyr}^{125} \mathrm{I}^{\mathrm{I}} \mathrm{T}_{4}$ was progressively degraded with time, and the rate of degradation was greatest during the first 15 min during which time 20$25 \%$ of the label was destroyed. Of the total $\left[\mathrm{Tyr}^{125} \mathrm{I}\right] \mathrm{T}_{4}$ degraded, $40-50 \%$ was recovered as [ ${ }^{125}$ I]DIT at 60 min. $^{2}$

\footnotetext{
2 The following calculations of the generation of DIT from $T_{4}$ have assumed that the production and degradation rates of this compound were linear during the sampling periods. The degradation of DIT was found to be $0-5 \mathrm{~min}, 2.4 \%$; $5-$ $15 \mathrm{~min}, 6.6 \% ; 15-30 \mathrm{~min}, 3.3 \% ; 30-60 \mathrm{~min}, 0.9 \%$. Therefore, the degradation rates of DIT per minute between these time periods were $0.48,0.66,0.22$, and $0.33 \%$ respectively. Based on these calculated rates of degradation, it was found that during a 60 -min incubation, $\left[{ }^{123}\right.$ I]DIT accounted for $15.3 \%$
}

$\left[{ }^{125} \mathrm{I}\right] \mathrm{NEI}$ was formed when either [Tyr $\left.{ }^{125} \mathrm{I}\right] \mathrm{T}_{4}$ or [Phen ${ }^{125}{ }^{12} \mathrm{~T}_{4}$ was used in the incubation medium. When $\left[\right.$ Tyr $\left.^{125}{ }^{12}\right] \mathrm{T}_{4}$ was used, $<2 \%$ of the $\left[{ }^{125} \mathrm{I}\right] \mathrm{NEI}$ formed could be ascribed to the prior degradation of [ ${ }^{125}$ I]DIT.

Similarly, it was estimated that $10-25 \%$ of the [ ${ }^{125}$ I]iodide formed after a 60 -min incubation was due to the degradation of $\left[{ }^{125} \mathrm{I}\right] \mathrm{DIT}$.

The relative contributions of $\left[{ }^{125} \mathrm{I}\right] \mathrm{MIT},\left[{ }^{125} \mathrm{I}\right] \mathrm{DIT}$, and $\left.{ }^{125} \mathrm{I}\right] \mathrm{T}_{4}$ to the formation of NEI were determined by pronase hydrolysis of the reaction products. The hydrolysate was initially chromatographed on Dowex to retain the MIT, DIT, and $\mathrm{T}_{4}$ radioactivity. Approximately $50 \%$ of the radioactivity applied to the column was retained, and further analysis of this radioactivity on Sephadex G-25 revealed that the major constituents were [ ${ }^{125}$ I]MIT $(27 \%)$ and material that migrated with $\left[{ }^{125} \mathrm{I}\right] \mathrm{T}_{4}(55 \%)$. A small amount of void volume material (14\%) and [ ${ }^{125}$ I]DIT $(4 \%)$ were also found in the hydrolysates.

\section{Effect of unlabeled $T_{4}$ on the degradation of $\left[{ }^{125} \mathrm{I}\right] T_{4}$}

To assess whether the process responsible for ELC was saturable, the effect of adding increasing amounts of unlabeled $T_{4}$ to the incubation medium was studied.

of the total radioactivity present. This figure is somewhat higher than that of $14.7 \%$ (17.4-2.7\%) given in Table I. Similar calculations were made for the generation of NEI and iodide from DIT.

940 Burger et al. 
The percentage of $\left[\right.$ Phen $\left.{ }^{125} \mathrm{I}\right] \mathrm{T}_{4}$ degraded was progressively and significantly decreased by the presence of unlabeled $\mathrm{T}_{4}$ in concentrations $>20 \mathrm{pmol}$. When 2,000 pmol was added, $8.0 \pm 0.2 \%$ of the $\left[{ }^{125} \mathrm{I}\right] \mathrm{T}_{4}$ was degraded at 60 min compared with $32.4 \pm 6.3 \%$ in the control tubes $(P<0.001, n=6)$.

\section{Effect of aminotriazole on ELC of $T_{4}$ in normal leukocytes (Table II)}

The experiments outlined above have demonstrated that ELC was abolished by heating the leukocytes (Table I), and that the process was saturable by an excess of unlabeled $T_{4}$. These findings suggested that the process was enzymic in nature. To further test this hypothesis, experiments were performed with the catalase inhibitor aminotriazole (Table II).

When incubated for $30 \mathrm{~min}$ with nonactivated leukocytes, aminotriazole $(20 \mu \mathrm{mol})$ had no effect upon the degradation of $\left[\mathrm{Tyr}^{125} \mathrm{I}\right] \mathrm{T}_{4}$. A slight, but significant effect on [Tyr $\left.{ }^{125} \mathrm{I}\right] \mathrm{T}_{4}$ degradation occurred at $60 \mathrm{~min}$. In contrast, when added to zymosan-activated leukocytes, $0.01 \mu \mathrm{mol}$ of aminotriazole caused a significant enhancement of the degradation of $\left[T_{y r}{ }^{125} \mathrm{I}\right] \mathrm{T}_{4}$. This effect was seen 5 min after the commencement of the incubation. At lower concentrations of aminotriazole $(0.002 \mu \mathrm{mol})$, no effect on $\left[\mathrm{Tyr}^{125} \mathrm{I}\right] \mathrm{T}_{4}$ degradation was observed, while at higher concentrations $(0.1-2 \mu \mathrm{mol})$, the degradation of $\left[\mathrm{Tyr}^{125} \mathrm{I}\right] \mathrm{T}_{4}$ was extremely rapid.

\section{Effect of PTU on ELC of $T_{4}$ in normal leukocytes}

The peroxidase inhibitor PTU was found to be a potent inhibitor of the ELC of $\mathrm{T}_{4}$ in zymosan-activated leukocytes. When concentrations of $0.4-2 \mu \mathrm{mol}$ were added to the incubation mixture, $\left[\mathrm{Tyr}^{125} \mathrm{I}\right] \mathrm{T}_{4}$ degradation was completely inhibited when assessed at $60 \mathrm{~min}$

\section{Metabolism of $T_{4}$ in leukocytes from patients with chronic granulomatous disease}

The experiments with aminotriazole and PTU suggested that the enzyme that mediates ELC is a peroxidase, and that $\mathrm{H}_{2} \mathrm{O}_{2}$ is a necessary cofactor in the reaction. To test this hypothesis further, studies were performed with leukocytes from three patients with chronic granulomatous disease, as these cells are unable to generate $\mathrm{H}_{2} \mathrm{O}_{2}$ during phagocytosis.

When $\left[\mathrm{Tyr}^{125} \mathrm{I}\right] \mathrm{T}_{4}$ was incubated with zymosan-activated cells from patients with chronic granulomatous disease, it was not degraded and $\left[{ }^{125} \mathrm{I}\right] \mathrm{DIT},\left[{ }^{125} \mathrm{I}\right] \mathrm{NEI}$, and ${ }^{125}$ I] iodide were not produced. These findings demonstrated that ELC does not occur in chronic granulomatous disease, and that $\left[{ }^{[25} \mathrm{I}\right] \mathrm{NEI}$ and $\left[{ }^{125} \mathrm{I}\right]$ iodide are generated by processes directly related to those that result in ELC.

\section{ELC of $T_{4}$ in Swiss-type acatalasemia}

The importance of leukocyte $\mathrm{H}_{2} \mathrm{O}_{2}$ was further assessed in the leukocytes of two subjects homozygous for Swiss-type acatalasemia. The cells of these individuals contained markedly decreased amounts of catalase, an enzyme partly responsible for the detoxification of $\mathrm{H}_{2} \mathrm{O}_{2}$ generated during phagocytosis. These cells metabolized [ $\left.T y{ }^{125}{ }^{12}\right] \mathrm{T}_{4}$ at the same rate as did the control leukocytes, and the products of metabolism were identical with those produced by the control cells (Fig. 3).

TABLE II

Enhancement of Ether Link Cleavage of $T_{4}$ by Aminotriazole in Normal Leukocytes

\begin{tabular}{|c|c|c|c|c|c|c|}
\hline \multirow[b]{2}{*}{ Zymossun } & \multirow[b]{2}{*}{ Aminotriazole } & \multicolumn{5}{|c|}{ Inculbation time $(\mathrm{min})$} \\
\hline & & 0 & 5 & 15 & 30 & 60 \\
\hline A Present & $\stackrel{\mu \text { mol }}{-}$ & & $91.3 \pm 1.4(4)^{\circ} t$ & $81.3 \pm 3.1(4)$ & $78.8 \pm 3.3(4)$ & $77.5 \pm 3.3(4)$ \\
\hline B & 0.002 & $92.0 \pm 0.8(5)$ & $90.3 \pm 2.1(4)$ & $76.0 \pm 3.9(5) \S$ & $75.5 \pm 4.6(5)^{\prime \prime} \S$ & $72.8 \pm 4.0(4) \pi \circ \circ$ \\
\hline C & 0.01 & $91.2 \pm 1.1(6)$ & $71-79(2) \ddagger$ & $49-57(2)$ & $54.2 \pm 5.7(6)\rfloor \S$ & $50.0 \pm 5.7(6) 11^{\circ}$ \\
\hline D & $0.1,0.2,2$ & $90.5 \pm 0.8$ & $62.8 \pm 0.9(4)^{\circ}$ & $36.0 \pm 3.4(4)^{\circ \circ}$ & $28.0 \pm 1.2(4)^{\circ}$ & $22.8 \pm 1.3(4)^{\circ}$ \\
\hline E Absent & - & $93.0 \pm 0.5(4)$ & $93.3 \pm 0.6(4)$ & $94.0 \pm 0.8(4)$ & $93.3 \pm 0.5$ & $92.8 \pm 0.5(4)$ \\
\hline $\mathrm{F}$ & 20 & $92.8 \pm 0.5$ & $93.0 \pm 0.4$ & $93.4 \pm 0.4(3)$ & $92.8 \pm 0.5(3)$ & $89.4 \pm 0.6(3) \S$ \\
\hline $\begin{array}{l}\text { G Present, } \\
\text { boiled cells }\end{array}$ & 20 & $92.5 \pm 0.6(4)$ & $93.1 \pm 0.5(4)$ & $92.0 \pm 0.4(4)$ & $91.2 \pm 0.8$ & $91.6 \pm 0.8(4)$ \\
\hline
\end{tabular}

- Percentage of total radioactivity (mean \pm SEM).

Numbers in parentheses represent the number of flasks.

$\S P<0.01$ vs. $\mathrm{E}$.

" $P<0.05$ B vs. C.

I $P<0.025$ B vs. C.

$\because P<0.001$ vs. $\mathrm{E}$.

$\llbracket$ $P<0.001 \mathrm{C}$ vs. D. 


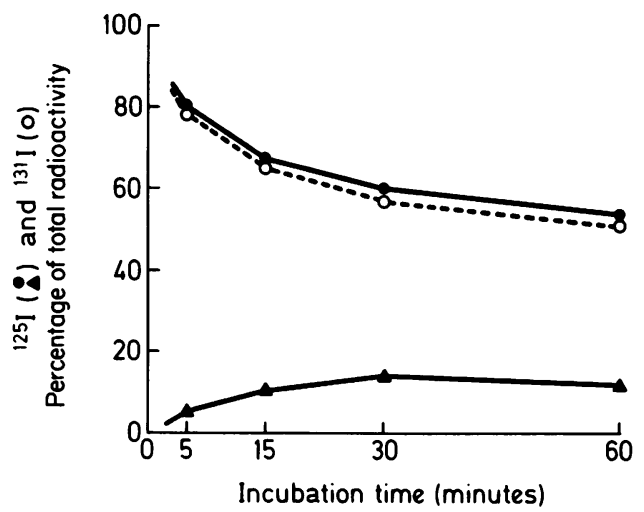

Figure 3 Degradation of [Tyr ${ }^{125} \mathrm{I}^{1} \mathrm{~T}_{4}(\bullet)$ by $10^{7}$ zymosanactivated leukocytes obtained from two subjects homozygous for Swiss-type acatalasemia. These leukocytes degraded [Tyr $\left.{ }^{125} \mathrm{I}\right] \mathrm{T}_{4}$ at the same rate as $\left[\right.$ Phen $\left.{ }^{131} \mathrm{I}\right] \mathrm{T}_{4}(\mathrm{O})$ and produced $\left[{ }^{125} \mathrm{I}\right] \mathrm{DIT}(\mathbf{\Delta})$.

\section{Effect of aminotriazole on $T_{4}$ degradation in Swiss-type acatalasemia (Table III)}

Since the leukocytes of subjects with Swiss-type acatalasemia are not completely devoid of catalase, further experiments were undertaken in which the remaining enzymatic activity was inhibited by aminotriazole.

0.002 and $0.01 \mu \mathrm{mol}$ of aminotriazole were used in these studies, as these concentrations were found to be optimal for the enhancement of ELC in normal cells (Table III). The leukocytes of subject 1 degraded [Tyr ${ }^{125} \mathrm{IJT}_{4}$ more actively than did cells from subject 2 or the control cells. However, the enhancement of ELC by aminotriazole was identical in the catalase-deficient and the normal leukocytes.

\section{Products of $T_{4}$ metabolism in Swiss-type acatalasemia (Table IV)}

The incubation of [Tyr ${ }^{125} \mathrm{I}^{\mathrm{T}} \mathrm{T}_{4}$ with zymosan-activated catalase-deficient leukocytes produced [ $\left.{ }^{125} \mathrm{I}\right] \mathrm{DIT}$ and $\left[{ }^{125} \mathrm{I}\right] \mathrm{NEI}$. Both the products formed in these cells and their percent generation were identical to those seen in normal cells.

\section{Effect of exogenous $\mathrm{H}_{2} \mathrm{O}_{2}$} on the metabolism of $T_{4}$

These experiments were conducted to assess whether a large amount of $\mathrm{H}_{2} \mathrm{O}_{2}$ could activate ELC in normal

TABLE III

Effect of Aminotriazole on Ether Link Cleavage of $T_{4}$ in Normal and Catalase-deficient Leukocytes

\begin{tabular}{|c|c|c|c|c|c|c|c|}
\hline \multirow[b]{2}{*}{ Subjects } & \multirow[b]{2}{*}{ Zymosan } & \multirow[b]{2}{*}{ Aminotriazole } & \multicolumn{5}{|c|}{ Incubation time (min) } \\
\hline & & & $\mathbf{0}$ & 5 & 15 & 30 & 60 \\
\hline & & $\mu \mathrm{mol}$ & & & & & \\
\hline 1 & Absent & - & $92^{\circ}$ & 93 & 93 & 98 & 92 \\
\hline 2 & & & 90 & 92 & 92 & 91 & 92 \\
\hline $\mathrm{C} t$ & & & 92 & 92 & 92 & 92 & 92 \\
\hline 1 & & 20 & & 92 & 91 & 91 & 89 \\
\hline 2 & & & & 91 & 90 & 89 & 90 \\
\hline $\mathrm{C}$ & & & & 92 & 92 & 92 & 89 \\
\hline 1 & Present & - & & 86 & 67 & 62 & 54 \\
\hline 2 & & & & 85 & 67 & 59 & 61 \\
\hline $\mathrm{C}$ & & & & 87 & 72 & 69 & 67 \\
\hline 1 & & 0.002 & & 83 & 61 & 53 & 49 \\
\hline 2 & & & & 81 & 61 & 51 & 53 \\
\hline C & & & & 85 & 66 & 62 & 61 \\
\hline 1 & & 0.01 & 93 & & & 38 & $37 / 91 \S$ \\
\hline 2 & & & 94 & & & 39 & $40 / 92 \$$ \\
\hline C & & & 89 & & & 52 & $49 / 90 \$$ \\
\hline
\end{tabular}

- Percentage of total radioactivity per flask. \ Leukocytes from a control subject.

\& Leukocytes were boiled before incubation. 
TABLE IV

Products of Ether Link Cleavage of $T_{4}$ in Normal and

Catalase-deficient Leukocytes

\begin{tabular}{|c|c|c|c|c|c|c|c|c|}
\hline \multirow[b]{2}{*}{ Subject } & \multirow[b]{2}{*}{ Product } & \multicolumn{2}{|c|}{ Incubation conditions } & \multicolumn{5}{|c|}{ Incubation time ( $\min )$} \\
\hline & & Zymosan & Aminotriazole & 0 & 5 & 15 & 30 & 60 \\
\hline & & & $\mu \mathrm{mol}$ & & & & & \\
\hline 1 & {$\left[{ }^{125} \mathrm{I}\right] \mathrm{DIT}$} & Present & Absent & $3.1^{\circ}$ & 8 & 19 & 20 & 23 \\
\hline 2 & & & & 4.5 & 8.6 & 20 & 23 & 21 \\
\hline $\mathrm{C} \ddagger$ & & & & 3.8 & 7.3 & 18 & 19 & 18 \\
\hline 1 & {$\left[{ }^{125} \mathrm{I}\right] \mathrm{NEI}$} & & & - & 1.1 & 6.9 & 11 & 15 \\
\hline 2 & & & & - & 1.6 & 6.7 & 12 & 13 \\
\hline $\mathrm{C}$ & & & & - & 1.0 & 5 & 7.3 & 10 \\
\hline 1 & {$\left[{ }^{125} \mathrm{I}\right] \mathrm{DIT}$} & Present & 0.01 & - & - & - & 26 & 27 \\
\hline 2 & & & & - & - & - & 31 & 31 \\
\hline $\mathrm{C}$ & & & & - & - & - & 26 & 27 \\
\hline 1 & {$\left[{ }^{125} \mathrm{I}\right] \mathrm{NEI}$} & & & - & - & - & 19 & 20 \\
\hline 2 & & & & - & - & - & 15 & 17 \\
\hline $\mathrm{C}$ & & & & - & - & - & 11 & 15 \\
\hline
\end{tabular}

- Percentage of total radioactivity per flask.

$\downarrow$ Leukocytes from a control subject.

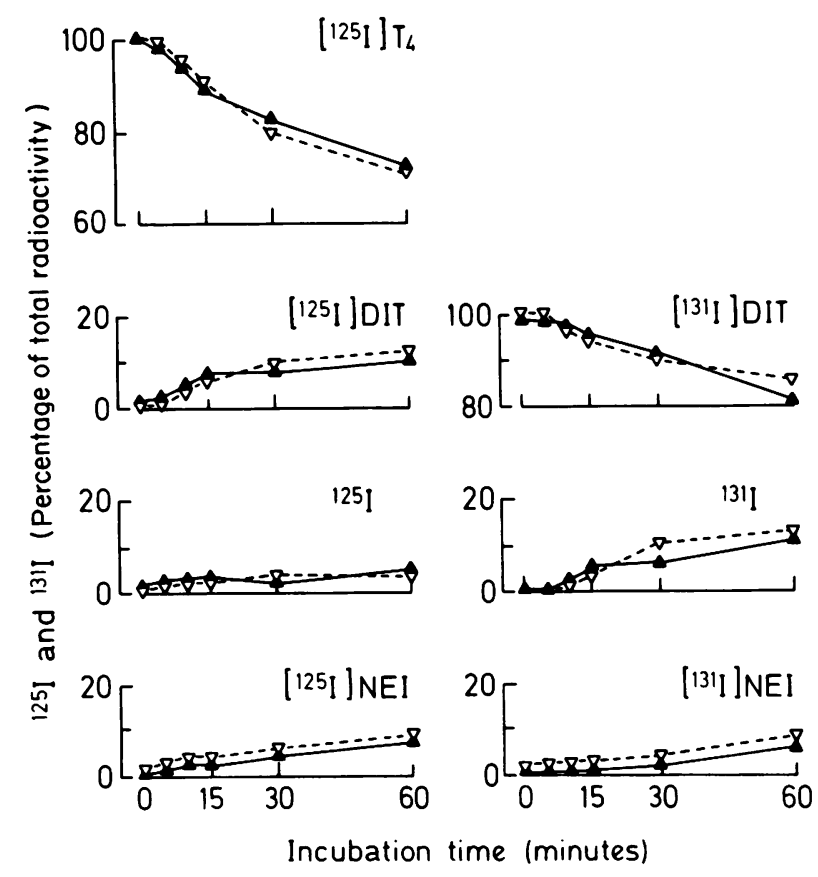

Fic:Url: 4 The metabolism of $\left[\right.$ Tyr $\left.^{125} \mathrm{I}\right] \mathrm{T}_{4}$ and $\left[{ }^{131} \mathrm{I}\right] \mathrm{DIT}$ by MPO-deficient $(\Delta)$ and normal $(\nabla)$ human leukocytes. The metabolism of [ $\left.T y r^{125} I\right] \mathrm{T}_{4}$ produced $\left[{ }^{125} \mathrm{I}\right] \mathrm{DIT}$, [ $\left.{ }^{125} \mathrm{I}\right] \mathrm{NEI}$, and $\left[{ }^{125}\right.$ I] iodide, whereas the metabolism of $\left[{ }^{131}\right.$ I]DIT produced $\left[{ }^{131} I\right] N E I$ and $\left[{ }^{131} I\right]$ iodide. No significant differences in the metabolism of these compounds was observed between the MPO-deficient and the control leukocytes. leukocytes. $300 \mu \mathrm{mol}$ of $\mathrm{H}_{2} \mathrm{O}_{2}$ was added, as this amount has been used as a substrate for the thyroid peroxidase. $\mathrm{H}_{2} \mathrm{O}_{2}$ failed to induce ELC when added to nonactivated leukocytes, and in two experiments $\mathrm{H}_{2} \mathrm{O}_{2}$ did not increase the rate of degradation of [Tyr ${ }^{125} \mathrm{I}_{2} \mathrm{~T}_{4}$ in zymosan-activated leukocytes.

\section{Metabolism of $T_{4}$ by myeloperoxidase- deficient leukocytes}

$\left[T_{y r}{ }^{125} \mathrm{I}\right] \mathrm{T}_{4}$ was incubated with the cells obtained from one patient with complete myeloperoxidase (MPO) deficiency (Fig. 4). When compared with the control leukocytes, there was no difference in the extent to which the MPO-deficient cells degraded [Tyr ${ }^{125} I_{T} T_{4}$. In addition, the degradation of DIT, as assessed by the metabolism of $\left[{ }^{131} \mathrm{I}\right] \mathrm{DIT}$, was also similar to that observed in the control cells.

\section{Induction of ELC by $\mathrm{H}_{2} \mathrm{O}_{2}$ and HRP}

In these studies [ $\left.T y r^{125} \mathrm{I}\right] \mathrm{T}_{4}$ was incubated with $\mathrm{H}_{2} \mathrm{O}_{2}$ and HRP in the absence of leukocytes. The experiments were performed with KRPG buffer containing $0.05 \%$ bovine serum albumin. Three experiments were performed in which the concentration of $\mathrm{H}_{2} \mathrm{O}_{2}$ was kept constant at $300 \mu \mathrm{mol}$, and the results of one of these experiments is shown in Fig. 5. This experiment 


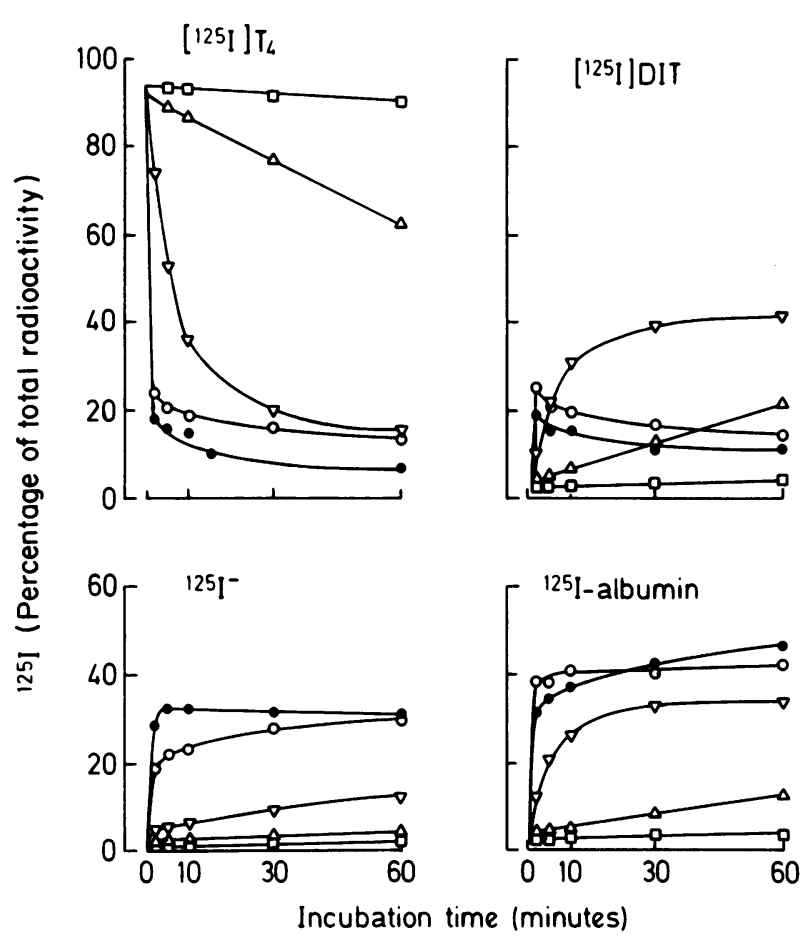

Figure 5 The effect of incubating [ $T y r^{125} \mathrm{I}^{1} \mathrm{~T}_{4}$ with $\mathrm{H}_{2} \mathrm{O}_{2}$ $(300 \mu \mathrm{mol})$ and HRP. The amounts of HRP added were 0.01 $(\square), 0.1(\Delta), 1(\nabla), 10(O)$, and $100(\bullet) \mu \mathrm{g}$.

demonstrated that $\left[T_{y r}{ }^{125}{ }^{1}\right] \mathrm{T}_{4}$ was degraded with time, and that the rate and extent of its degradation increased as the concentration of HRP was increased. When $1 \mu \mathrm{g}$ HRP was used, the percentage of the radioactivity found as [ ${ }^{125}$ I]DIT was greater than that found as ${ }^{125} \mathrm{I}$-albumin and $\left.{ }^{125} \mathrm{I}\right]$ iodide, and the use of this concentration of HRP provided the best demonstration of ELC. However, when higher concentrations of HRP were used, a greater percentage of the label was found as ${ }^{125} \mathrm{I}$-albumin and $\left[{ }^{125} \mathrm{I}\right]$ iodide than as [ ${ }^{125}$ I]DIT. To explain these findings, the metabolism of [ $\left.{ }^{131} \mathrm{I}\right] \mathrm{DIT}$ by $\mathrm{H}_{2} \mathrm{O}_{2}$ and HRP was examined. These studies demonstrated that $74 \%$ of the $\left.{ }^{131} \mathrm{I}\right] \mathrm{DIT}$ was degraded in 2 min when $100 \mu \mathrm{g}$ HRP was present in the reaction mixture. These findings demonstrated therefore that DIT was also subject to degradation, and at concentrations of HRP $>1 \mu \mathrm{g}$, its rate of degradation exceeded its rate of formation.

\section{Monodeiodination of $T_{4}$ by normal leukocytes (Table V)}

These experiments were performed to assess the relative importance of $5^{\prime}$-deiodination in the metabolism of $\mathrm{T}_{4}$ during leukocyte phagocytosis. [Phen $\left.{ }^{131} \mathrm{I}\right] \mathrm{T}_{4}$ and $\left[P\right.$ hen $\left.^{125} \mathrm{I}\right] \mathrm{T}_{3}$ were incubated with phagocytosing cells,
TABLE V

T, 5'-Monodeiodination in Normal Leukocytes

\begin{tabular}{cccc}
\hline & & \multicolumn{2}{c}{ Incubation time (min) } \\
\cline { 3 - 4 } Zymosan & $\begin{array}{c}\text { Leukocyte } \\
\text { number }\end{array}$ & 30 & 60 \\
\hline Absent & Nil & - & $0.4 / 0.25^{\circ}$ \\
Present & Nil & - & $0.4 / 0.34$ \\
Absent & $10^{7}$ & $0.83 / 0.82$ & $0.7 / 0.76$ \\
Present & $10^{7}$ & $0.92 / 0.67$ & $0.78 / 0.50$ \\
\hline
\end{tabular}

- Percent $\left[{ }^{131} \mathrm{I}\right] \mathrm{T}_{3}$ formed from $\left[{ }^{131} \mathrm{I}\right] \mathrm{T}_{4}$.

$\ddagger$ Results obtained from two separate experiments.

the $\left[{ }^{125} \mathrm{I}\right] \mathrm{T}_{3}$ serving as a recovery standard. In two separate experiments, the percentage of $\left[{ }^{131} \mathrm{I}\right] \mathrm{T}_{4}$ converted to $\left[{ }^{131} \mathrm{I}\right] \mathrm{T}_{3}$ was $<0.5 \%$.

Studies of the degradation of [Phen $\left.{ }^{125} \mathrm{I}\right] \mathrm{T}_{3},[$ Phen $\left.{ }^{125} \mathrm{I}\right] \mathrm{r} \mathrm{T}_{3}$, and $\left[{ }^{125} \mathrm{I}\right] 3,5-\mathrm{T}_{2}$ during a 60 -min incubation revealed that the percent degradation of these iodothyronines was similar to that of $\left[\right.$ Phen $\left.{ }^{131}{ }^{13}\right] \mathrm{T}_{4}$. (Percent degradation of $\left[{ }^{125} \mathrm{I}\right] \mathrm{T}_{3}, 52 \pm 4 \% ;\left[{ }^{125} \mathrm{I}\right] \mathrm{r} \mathrm{T}_{3}, 50 \pm 5 \%$; $\left[{ }^{125} \mathrm{I}\right] 3,5-\mathrm{T}_{2}, 54 \pm 10 \% ;\left[{ }^{131} \mathrm{I}\right] \mathrm{T}_{4}, 55 \pm 10 \%$.) These results therefore demonstrated that an enhanced rate of degradation of $T_{3}$ could not account for the relatively little $\mathrm{T}_{4} 5^{\prime}$-deiodination observed. They also demonstrated that iodothyronine degradation was independent of the position of the label, further supporting the suggestion that each compound was subject to oxidative degradation.

\section{Demonstration of ELC in vivo (Table VI)}

To demonstrate the production of [ $\left.{ }^{125} \mathrm{I}\right] \mathrm{DIT}$ in vivo, 25 rats were given a single subcutaneous injection of $\left[{ }^{125} \mathrm{I}\right] 3,5-\mathrm{T}_{2}$. The solution containing this iodothyronine also contained $1.5 \%$ of $\left[{ }^{125}\right.$ I]DIT as an impurity and initial experiments were therefore performed to examine the disappearance of DIT from serum. This was achieved by adding $\left[{ }^{131} I\right] D I T$ to the $\left[{ }^{125} I\right] 3,5-T_{2}$ solution. After the injection, $\left[{ }^{131} I\right] D I T$ disappeared more rapidly from serum than did $\left.{ }^{125} I\right] 3,5-T_{2}$ (Fig. 6 ). When the ratio of $\left[{ }^{125} I\right] D I T /\left[{ }^{125} \mathrm{I}\right] 3,5-\mathrm{T}_{2}$ was calculated, it was found to be constant over $2 \mathrm{~h}$ (Table VI). This suggested the de novo production of [ ${ }^{125}$ I]DIT from $\left[{ }^{125} \mathrm{I}\right] 3,5-\mathrm{T}_{2}$; had [ $\left.{ }^{125} \mathrm{I}\right] \mathrm{DIT}$ not been formed, one would have expected a rapid decrease in serum [ $\left.{ }^{125} \mathrm{I}\right] \mathrm{DIT}$ and in the $\left[{ }^{125} \mathrm{I}\right] \mathrm{DIT} /\left[{ }^{125} \mathrm{I}\right] 3,5-\mathrm{T}_{2}$ ratio. This conclusion is strengthened by the observation that the [ $\left.{ }^{125} \mathrm{I}\right] \mathrm{DIT} /$ [ ${ }^{131}$ I]DIT ratio was also significantly increased (Table VI). $4 \mathrm{~h}$ after the injection, $\left.{ }^{[31} \mathrm{I}\right] \mathrm{DIT}$ had disappeared 


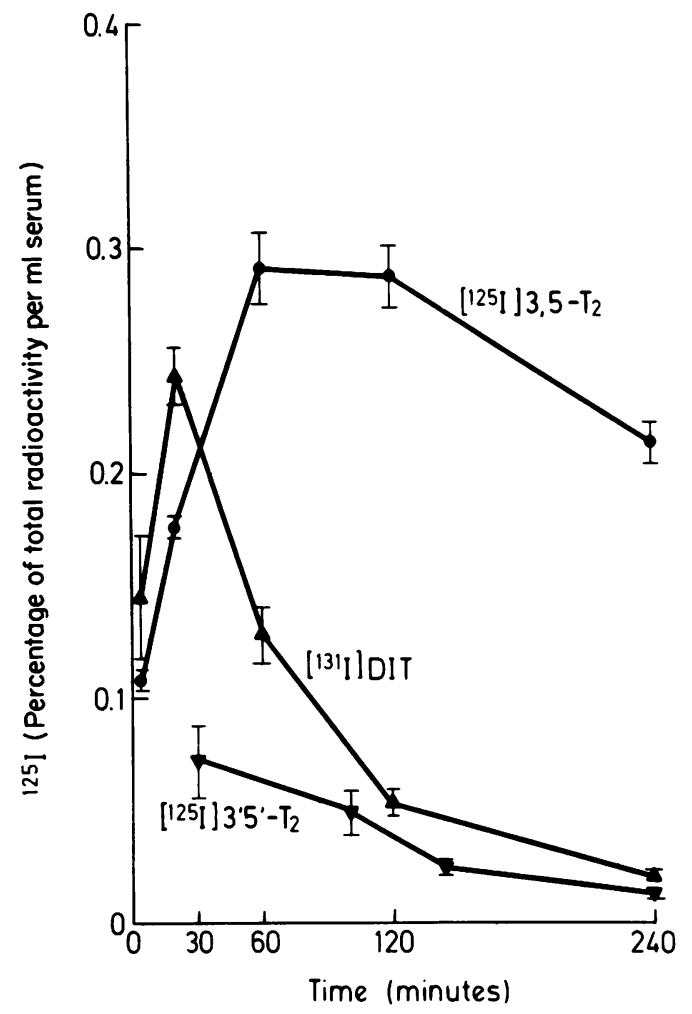

FIGURE 6 The serum disappearance of $\left[{ }^{125} \mathrm{I}\right] 3,5-\mathrm{T}_{2},\left[{ }^{131} \mathrm{I}\right] \mathrm{DIT}$, and $\left[{ }^{125} I\right] 3,5-T_{2}$ in the rat. Each point represents the mean $\pm S E M$ of five animals.

from the serum, but chromatographic identification of [ ${ }^{125}$ I]DIT was still possible (Fig. 7, panel A).

To exclude the possibility that the formation of [25I]DIT was due to the iodination of endogenous tyrosine, 16 rats were also injected with $\left[{ }^{125} \mathrm{I}\right] 3^{\prime}, 5^{\prime}-\mathrm{T}_{2}$ and [ $\left.{ }^{131} I\right] D I T$. Although [ $\left.{ }^{125} I\right] 3^{\prime}, 5^{\prime}-T_{2}$ disappeared more rapidly than $\left[{ }^{125} \mathrm{I}\right] 3,5-\mathrm{T}_{2}$ (Fig. 6 ), $\left[{ }^{125} \mathrm{I}\right] \mathrm{DIT}$ was not demonstrated at any time (Fig. 7, panel B).

TABLE VI

Ether Link Cleavage in Vivo

\begin{tabular}{|c|c|c|}
\hline $\begin{array}{c}\text { Time after injection } \\
\text { of }\left[{ }^{125}[]_{3}, 5-T_{2} \text { and }{ }^{[131} I\right] D I T\end{array}$ & {$\left[{ }^{125}\right] \mathrm{DIT} /\left[^{125} \mathrm{I}\right] 3,5-\mathrm{T}_{2}$} & {$\left[{ }^{125} \mathrm{I}\right] \mathrm{DIT} /\left[{ }^{131}\right] \mathrm{DIT}$} \\
\hline $5 \min$ & $0.003 \pm 0.0003$ & $0.117 \pm 0.059^{\circ}$ \\
\hline $20 \mathrm{~min}$ & $0.0026 \pm 0.0001$ & $0.068 \pm 0.004 !$ \\
\hline $1 \mathrm{~h}$ & $0.0015 \pm 0.0001$ & $0.130 \pm 0.004 \S$ \\
\hline $2 \mathrm{~h}$ & $0.003 \pm 0.0002$ & $0.669 \pm 0.148$ \\
\hline $4 \mathrm{~h}$ & - & - \\
\hline
\end{tabular}

- $P=\mathrm{NS}, 5 \mathrm{~min}$ vs. $20 \mathrm{~min}$.

t $P<0.0005,20 \mathrm{~min}$ vs. $1 \mathrm{~h}$.

$\S P<0.005,1 \mathrm{~h}$ vs. $2 \mathrm{~h}$.

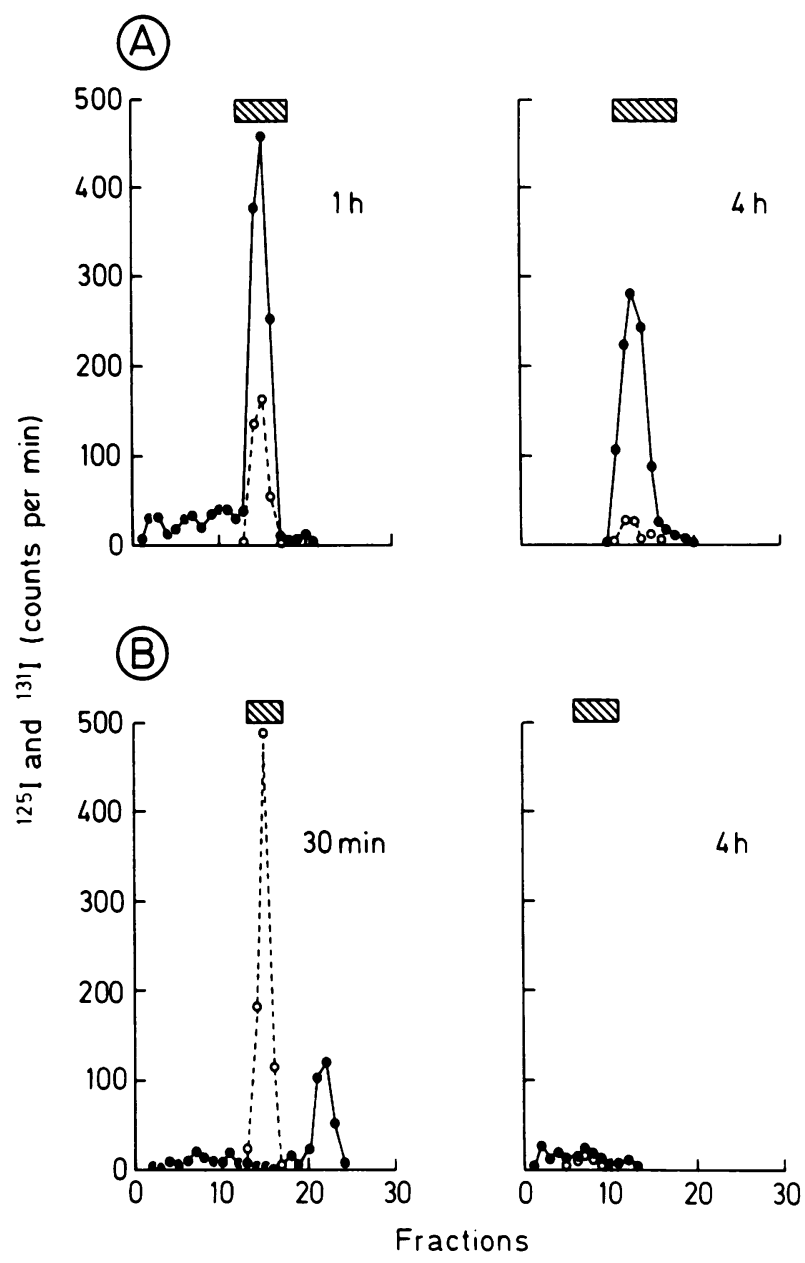

Figure 7 Cation exchange chromatography of serum obtained at various intervals from rats injected with (A) $\left[{ }^{125} I\right] 3,5-T_{2}$ or $(B)\left[{ }^{125} I\right] 3^{\prime}, 5^{\prime}-T_{2}$. The $\left[{ }^{125} I\right] D I T$ in the sera was initially isolated by immunoprecipitation (Methods), and the $\left[{ }^{125}\right.$ I]DIT in the samples was pooled and applied to the column. The [ $\left.{ }^{125} I\right] D I T$ peak $(0)$ coincided exactly with the ${ }^{[31}$ I]DIT peak (O), and with the elution profile of unlabeled DIT as measured by radioimmunoassay (hatched area).

\section{DISCUSSION}

These studies have demonstrated that $T_{4}$ is degraded by human leukocytes by ELC during phagocytosis. This conclusion is based on the demonstration of the appearance of labeled DIT as a product of $T_{4}$ labeled with radioiodine in its tyrosyl ring. ELC is the major pathway for the disposal of $T_{4}$ in the phagocytosing leukocyte, as $40-50 \%$ of all the $\mathrm{T}_{4}$ degraded was converted into DIT. In addition to DIT, labeled iodide and NEI were also produced, and these two compounds were formed when either phenolic or tyrosyl ring-labeled $T_{4}$ was the substrate. The generation of 
NEI, or iodoprotein, from the degradation of both rings of the $T_{4}$ molecule confirms and extends the observations of previous workers $(17,18)$, and indicates that the phagocytosing leukocyte is yet another source of the iodoprotein that is generated by the metabolism of the thyroid hormones in peripheral tissues (26-30).

The relationship of the NEI to the processes mediating ELC was further investigated by subjecting this component to pronase hydrolysis and to chromatographic analysis. The major constituents of the NEI were labeled MIT and material which migrated in the area of $T_{4}$. Labeled MIT was found in the digests when either phenolic or tyrosyl ring-labeled $\left[{ }^{125} \mathrm{I}\right] \mathrm{T}_{4}$ was used suggesting that its formation results from the iodination of leukocyte tyrosine residues, rather than from the deiodination of DIT. Since labeled MIT, rather than DIT, was found, these studies suggest that a major causal relationship between the process mediating ELC and NEI formation is unlikely. The presence of labeled $\mathrm{T}_{4}$ in the hydrolysates suggests that covalent protein binding of this iodothyronine occurs once the hormone has been taken up by the leukocyte. ELC of $T_{4}$, occurring before or after the covalent binding of the molecule, would account for the small quantities of labeled DIT present.

ELC was decreased in the presence of excess unlabeled $\mathrm{T}_{4}$, and was abolished by preheating the leukocytes. These observations suggested that the process mediating ELC was enzymic in nature. Further, the enhancement of ELC by the catalase inhibitor aminotriazole and its inhibition by the peroxidase inhibitor PTU suggested that the enzyme involved is a peroxidase and that $\mathrm{H}_{2} \mathrm{O}_{2}$ is necessary in the reaction. ${ }^{3}$ The observation that ELC was dormant in the resting leukocyte but was activated by the onset of phagocytosis suggested that the process might be related to the metabolic events that accompany phagocytosis.

The induction of phagocytosis is associated with a series of enzymatic events that are responsible for all of the oxygen-dependent killing by phagocytes. These reactions are collectively referred to as the "respiratory burst". During this sequence, there results an increase in oxygen uptake, superoxide $\left(\mathrm{O}_{2}^{-}\right)$production, $\mathrm{H}_{2} \mathrm{O}_{2}$ generation, and hexose monophosphate shunt activity (31-35). All the oxygen taken up during the respiratory burst is converted to $\mathrm{O}_{2}^{-}$, and $80 \%$ of this

\footnotetext{
${ }^{3}$ PTU only inhibits MPO whereas aminotriazole may inhibit both catalase and MPO. Since ELC was abolished by PTU but was enhanced by aminotriazole, it is unlikely that a significant inhibition of MPO activity by aminotriazole occurred during the reaction. Furthermore, in separate experiments, the degradation of labeled $\mathrm{T}_{4}$ by $\mathrm{HRP}$ and $\mathrm{H}_{2} \mathrm{O}_{2}$ was unaltered by the addition of aminotriazole in concentrations of up to $0.1 \mu \mathrm{mol}$.
}

$\mathrm{O}_{2}^{-}$is then converted to $\mathrm{H}_{2} \mathrm{O}_{2}$ by dismutation. This dismutation reaction is the only important source of the $\mathrm{H}_{2} \mathrm{O}_{2}$ generated during the respiratory burst (33). The hexose monophosphate shunt is in turn activated by the $\mathrm{NADP}^{+}$generated by the conversion of $\mathrm{O}_{2}$ to $\mathrm{O}_{2}^{-}$and by the glutathione peroxidase-glutathione reductase system. This cytosolic enzyme system is responsible for the detoxification of the $\mathrm{H}_{2} \mathrm{O}_{2}$ that leaks into the cytoplasm from the phagocytic vacuole during the respiratory burst (36).

With these considerations in mind, studies were undertaken to test the involvement of $\mathrm{H}_{2} \mathrm{O}_{2}$ in the process of ELC. Initial experiments were performed with the leukocytes of patients with chronic granulomatous disease. This inherited disorder is characterized by a greatly enhanced susceptibility to infection by certain strains of bacteria $(37,38)$. The leukocytes of affected individuals are able to ingest bacteria normally, but are unable to carry out the reactions of the respiratory burst (39-41). As a consequence, $\mathrm{H}_{2} \mathrm{O}_{2}$ is not generated and the activity of the hexose monophosphate shunt is not increased. In this regard, the inability of chronic granulomatous cells to degrade $T_{4}$ by ELC strongly suggests that this process is related to the reactions of the respiratory burst. These observations also provide an explanation for the defective iodinating capacity of these leukocytes (42).

To further evaluate the role of $\mathrm{H}_{2} \mathrm{O}_{2}$, the degradation of $T_{4}$ was examined in the leukocytes of subjects homozygous for Swiss-type acatalasemia. The neutrophils of these individuals have a catalase activity $<30 \%$ of that found in normal leukocytes (43). This enzyme, together with the glutathione redox system, is responsible for converting the $\mathrm{H}_{2} \mathrm{O}_{2}$ formed during the respiratory burst into water and oxygen. Catalase-deficient neutrophils are protected from oxidative damage by a normally functioning redox system, and secrete normal amounts of $\mathrm{H}_{2} \mathrm{O}_{2}$ into the extracellular medium during phagocytosis (44). ELC proceeded at a normal rate in these cells and was enhanced by aminotriazole to the same extent as were the control leukocytes. These observations provide further support for the suggestion that $\mathrm{H}_{2} \mathrm{O}_{2}$ concentrations are normal in catalase-deficient leukocytes, and add weight to the hypothesis that the glutathione redox system is the most important means of disposal of the $\mathrm{H}_{2} \mathrm{O}_{2}$ generated during the respiratory burst $(45,46)$.

The incubation of tyrosyl ring-labeled $\mathrm{T}_{4}$ with HRP and $\mathrm{H}_{2} \mathrm{O}_{2}$ resulted in the appearance of labeled DIT, NEI, and iodide, demonstrating that $\mathrm{H}_{2} \mathrm{O}_{2}$ and a peroxidase enzyme are involved in mediating the process of ELC. These findings confirm the work of previous authors that have demonstrated the degradation of the thyroid hormones by $\mathrm{H}_{2} \mathrm{O}_{2}$ and either $\operatorname{HRP}(47,48)$ 
or MPO (48) with the production of iodide and origin material (17). However, ELC was also found to occur in MPO-deficient leukocytes, suggesting that ELC may be mediated by cellular mechanisms involving more than the simple combination of MPO and $\mathrm{H}_{2} \mathrm{O}_{2}$. It is possible that there exists an MPO-independent system capable of degrading $T_{4}$, but the nature of such a system can only remain hypothetical at present.

The existence of ELC as an alternative in vivo pathway for the metabolism of the iodothyronines has also been demonstrated in these studies. This conclusion is based on the appearance in serum of labeled DIT after the subcutaneous injection of $\left[{ }^{125} \mathrm{I}\right] 3,5-\mathrm{T}_{2}$ in the rat. $\left[{ }^{125} \mathrm{I}\right] 3,5-\mathrm{T}_{2}$ was chosen to facilitate the demonstration of ELC, because this compound is metabolized more rapidly than is $\left[{ }^{125} \mathrm{I}\right] \mathrm{T}_{4}$. Previous studies that have sought to demonstrate ELC in vivo have yielded conflicting results. The studies of Pittman and Chambers (49) did not provide evidence in support of its existence, but these investigators injected rats with radiothyroxines rather than the more rapidly metabolized iodothyronines, and it is possible that a small percentage of $T_{4}$ being degraded by this route may have escaped detection. In contrast, the studies of Dratman et al. (50) have demonstrated the appearance of labeled DIT in the developing neuraxis of the tadpole after the injection of randomly labeled $\mathrm{T}_{4}$. More recently, Balsam et al. (51) have also confirmed the in vivo occurrence of ELC of $\mathrm{T}_{4}$. These authors demonstrated the appearance of labeled ketoacids of DIT in the urine of rats given tyrosyl ring-labeled $T_{4}$ and mononitrotyrosine, an inhibitor of the degradation of DIT.

It is possible that ELC of the iodothyronines may contribute to the overall bactericidal capacity of the leukocyte. The MPO-halide- $\mathrm{H}_{2} \mathrm{O}_{2}$ system is an important oxygen-dependent mechanism by which phagocytes kill ingested bacteria (52), and the chloride ion is likely to be the most important halide in this reaction because of its abundant intracellular concentration. However, the enhanced uptake of $\mathrm{T}_{4}$ during leukocyte phagocytosis, and its subsequent destruction by ELC would result in a series of compounds, the degradation of which would increase the intraleukocytic concentration of iodide. The iodide would then be available to combine with the MPO and $\mathrm{H}_{2} \mathrm{O}_{2}$ in the phagocytic vacuole and would be expected to increase the microbicidal activity of the leukocyte caused by iodination of the ingested bacteria (53). In addition, the demonstration of covalent binding of $T_{4}$ to intraleukocytic proteins suggests that ingested proteinaceous material, such as bacteria, could also be iodinated directly by the $\mathrm{T}_{4}$ molecule.

In summary, these studies have shown that the hu- man leukocyte is capable of degrading the iodothyronines by ELC. The pathway appears to be dormant in the nonactivated leukocyte, but becomes the major method of disposal of these compounds when phagocytosis is induced. Its in vivo occurrence in the rat demonstrates that this pathway is available for iodothyronine degradation in the basal, nonstressed state. Its activation during leukocyte phagocytosis suggests that its quantitative importance as a method of iodothyronine degradation may be increased during infectious illnesses, and that it could contribute in part to the acceleration of $T_{4}$ turnover that has been observed in these states (1-3). Its contribution to overall thyroid hormone economy in man and in the rat in various pathophysiological states requires further investigation.

\section{ACKNOWLEDGMENTS}

It is a pleasure to acknowledge the assistance of Dr. Hans Cahnmann in establishing some of the methods used in these studies.

The study was supported by Swiss National Foundation grants 3.925.0.78 and 3.812.0.81, and by US Public Health Service grants AI-11827 and AM-18416. Thanks are also due to l'Académie Suisse des Sciences Médicales for providing a travel grant for Albert Burger. Dennis Engler was also supported, in part, by grants from the Alfred Hospital Melbourne and the Ames Company, Australia.

\section{REFERENCES}

1. Sterling, K., and R. B. Chodos. 1956. Radiothyroxine turnover studies in myxedema, thyrotoxicosis, and hypermetabolism without endocrine disease. J. Clin. Invest. 35: 806-813.

2. Kaptein, E. M., W. J. Robinson, D. A. Grieb, and J. T. Nicoloff. 1982. Peripheral serum thyroxine, triiodothyronine, and reverse triiodothyronine kinetics in the low thyroxine state of acute nonthyroidal illnesses. A noncompartmental analysis. J. Clin. Invest. 69: 526-535.

3. Gregerman, R. I., and N. Solomon. 1967. Acceleration of thyroxine and triiodothyronine turnover during bacterial pulmonary infections and fever: implications for the functional state of the thyroid during stress and in senescence. J. Clin. Endocrinol. Metab. 27: 93-105.

4. Lutz, J. H., R. I. Gregerman, S. W. Spaulding, R. B. Hornick, and A. T. Dawkins, Jr. 1972. Thyroxine binding proteins, free thyroxine, and thyroxine turnover interrelationships during acute infectious illness in man. $J$. Clin. Endocrinol. Metab. 35: 230-249.

5. Wartofsky, L., D. Martin, and J. M. Earll. 1972. Alterations in thyroid iodine release and the peripheral metabolism of thyroxine during acute falciparum malaria in man. J. Clin. Invest. 51: 2215-2232.

6. DeRubertis, F. R., and K. A. Woeber. 1972. Evidence for enhanced cellular uptake and binding of thyroxine in vivo during acute infection with Diplococcus pneumoniae. J. Clin. Invest. 51: 788-795.

7. Chopra, I. J., D. H. Solomon, U. Chopra, S. Y. Wu, D. A. Fisher, and Y. Nakamura. 1978. Pathways of me- 
tabolism of thyroid hormones. Recent Prog. Horm. Res. 34: 521-567.

8. Gavin, L., J. Castle, P. McMahon, P. Martin, M. Hammond, and R. R. Cavalieri. 1977. Extrathyroidal conversion of thyroxine to $3,3^{\prime}, 5^{\prime}$-triiodothyronine (reverse$\mathrm{T}_{3}$ ) and to $3,5,3^{\prime}$-triiodothyronine $\left(\mathrm{T}_{3}\right)$ in humans. J. Clin. Endocrinol. Metab. 44: 733-742.

9. Nomura, S., C. S. Pittman, J. B. Chambers, Jr., M. W. Buck, and T. Shimizu. 1975. Reduced peripheral conversion of thyroxine to triiodothyronine in patients with hepatic cirrhosis. J. Clin. Invest. 56: 643-652.

10. Chopra, I. J. 1976. An assessment of daily production and significance of thyroidal secretion of $3,3^{\prime}, 5^{\prime}$-triiodothyronine (reverse $\mathrm{T}_{3}$ ) in man. J. Clin. Invest. 58: 3240.

11. Plaskett, L. G. 1961. Studies on the degradation of thyroid hormones in vitro with compounds labelled in either ring. Biochem. J. 78: 652-657.

12. Wynn, J., and R. Gibbs. 1962. Thyroxine degradation. II. Products of thyroxine degradation by rat liver microsomes. J. Biol. Chem. 237: 3499-3505.

13. Roche, J., J. Nunez, and C. Jacquemin. 1962. Nature des produits de la désiodation des hormones thyroidiennes marquées simultanément par le tritium et l'iode radioactif. Biochim. Biophys. Acta. 64: 475-486.

14. Siegel, E., and B. A. Sachs. 1964. In vitro leukocyte uptake of ${ }^{131}$ I-labeled iodide, thyroxine, and triiodothyronine, and its relation to thyroid function. J. Clin. Endocrinol. Metab. 24: 313-318.

15. Woeber, K. A. 1971. Alterations in thyroid hormone economy during acute infection with Diplococcus pneumoniae in the rhesus monkey. J. Clin. Invest. 50: 378387.

16. Woeber, K. A., G. F. Doherty, and S. H. Ingbar. 1972. Stimulation by phagocytosis of the deiodination of Lthyroxine in human leukocytes. Science (Wash. DC). 176: 1039-1041.

17. Klebanoff, S. J., and W. L. Green. 1973. Degradation of thyroid hormones by phagocytosing human leukocytes. J. Clin. Invest. 52: 60-72.

18. Woeber, K. A., and S. H. Ingbar. 1973. Metabolism of L-thyroxine by phagocytosing human leukocytes. $J$. Clin. Invest. 52: 1796-1803.

19. Burger, A. 1977. Diiodotyrosine, a product of $T_{4}$ metabolism in phagocytizing human leukocytes. Clin. Res. 25: 291a. (Abstr.)

20. Burger, A., and S. H. Ingbar. 1974. Labeling of thyroid hormones and their derivatives. Endocrinology. 94: 1189-1192.

21. Sorimachi, K., and H. J. Cahnmann. 1977. A simple synthesis of 3,5-( $\left.{ }^{125} \mathrm{I}\right)$-diiodo-L-thyronine and of 3,5-( $\left({ }^{125} \mathrm{I}\right)-\mathrm{L}$ thyroxine of high specific activity. Endocrinology. 101: $1276-1280$.

22. Sorimachi, K., and N. Ui. 1975. Ion exchange chromatographic analysis of iodothyronines. Anal. Biochem. 67: $157-165$

23. Bellabarba, D., R. E. Peterson, and K. Sterling. 1968. An improved method for chromatography of iodothyronines. J. Clin. Endocrinol. Metab. 28: 305-307.

24. Pincus, S. H., and S. J. Klebanoff. 1971. Quantitative leukocyte iodination. N. Engl. J. Med. 284: 744-750.

25. Sachs, L. 1974. Angewandte Statistik. Springer-Verlag, Berlin. 209-216.

26. Tata, J. R. 1960. Transiodination of proteins during enzymatic de-iodination of thyroxine. Nature (Lond.). 187: $1025-1026$
27. Galton, V. A., and S. H. Ingbar. 1961. The mechanism of protein iodination during the metabolism of thyroid hormones by peripheral tissues. Endocrinology. 69: 3038.

28. Nakagawa, S., and W. R. Ruegamer. 1967. Properties of a rat tissue iodothyronine deiodinase and its natural inhibitor. Biochemistry. 6: 1249-1261.

29. Surks, M. I., H. L. Schwartz, and J. H. Oppenheimer. 1969. Tissue iodoprotein formation during peripheral metabolism of the thyroid hormones. J. Clin. Invest. 48: 2168-2175.

30. Surks, M. I., and J. H. Oppenheimer. 1970. Composition of nonextractable radioactivity formed after injection of labeled L-thyroxine and 3,5,3'-triiodo-L-thyronine in rats. Endocrinology. 87: 567-575.

31. Babior, B. M., J. T. Curnutte, and B. J. McMurrich. 1976. The particulate superoxide-forming system from human neutrophils. Properties of the system and further evidence supporting its participation in the respiratory burst. J. Clin. Invest. 58: 989-996.

32. Goldstein, I. M., M. Cerqueira, S. Lind, and H. B. Kaplan. 1977. Evidence that the superoxide-generating system of human leukocytes is associated with the cell surface. J. Clin. Invest. 59: 249-254.

33. Root, R. K., and J. A. Metcalf. 1977. $\mathrm{H}_{2} \mathrm{O}_{2}$ release from human granulocytes during phagocytosis. Relationship to superoxide anion formation and cellular catabolism of $\mathrm{H}_{2} \mathrm{O}_{2}$ : studies with normal and cytochalasin B-treated cells. J. Clin. Invest. 60: 1266-1279.

34. Babior, B. M. 1978. Oxygen-dependent microbial killing by phagocytes. N. Engl. J. Med. 298: 659-668.

35. Dewald, B., M. Baggiolini, J. T. Curnutte, and B. M. Babior. 1979. Subcellular localization of the superoxideforming enzyme in human neutrophils. J. Clin. Invest. 63: 21-29.

36. Reed, P. W. 1969. Glutathione and the hexose monophosphate shunt in phagocytizing and hydrogen peroxide-treated rat leukocytes. J. Biol. Chem. 244: 24592464

37. Berendes, H., R. A. Bridges, and R. A. Good. 1957. A fatal granulomatosis of childhood: the clinical study of a new syndrome. Minn. Med. 40: 309-312.

38. Windhorst, D. B., A. R. Page, B. Holmes, P. G. Quie and R. A. Good. 1968. The pattern of genetic transmission of the leukocyte defect in fatal granulomatous disease of childhood. J. Clin. Invest. 47: 1026-1034.

39. Baehner, R. L., and D. G. Nathan. 1967. Leukocyte oxidase: defective activity in chronic granulomatous disease. Science (Wash. DC). 155: 835-836.

40. Curnutte, J. T., D. M. Whitten, and B. M. Babior. 1974 Defective superoxide production by granulocytes from patients with chronic granulomatous disease. N. Engl. J. Med. 290: 593-597.

41. Johnston, R. B., Jr., B. B. Keele, Jr., H. P. Misra, J. E. Lehmeyer, L. S. Webb, R. L. Baehner, and K. V. Rajagopalan. 1975. The role of superoxide anion generation in phagocytic bactericidal activity: studies with normal and chronic granulomatous disease leukocytes. J. Clin. Invest. 55: 1357-1372.

42. Klebanoff, S. J., and L. R. White. 1969. Iodination defect in the leukocytes of a patient with chronic granulomatous disease of childhood. N. Engl. J. Med. 280: 460466.

43. Wyss, S. R., and H. Aebi. 1975. Properties of leukocyte catalase in Swiss-type acatalasemia: a comparative study 
of normals, heterozygotes, and homozygotes. Enzyme (Basel). 20: 257-268.

44. Roos, D., R. S. Weening, S. R. Wyss, and H. E. Aebi. 1980. Protection of human neutrophils by endogenous catalase. Studies with cells from catalase-deficient individuals. J. Clin. Invest. 65: 1515-1522.

45. Roos, D., R. S. Weening, A. A. Voetman, M. L. J. van Schaik, A. A. M. Bot, L. J. Meerhof, and J. A. Loos. 1979. Protection of phagocytic leukocytes by endogenous glutathione: studies in a family with glutathione reductase deficiency. Blood. 53: 851-866.

46. Spielberg, S. P., L. A. Boxer, J. M. Oliver, J. M. Allen, and J. D. Schulman. 1979. Oxidative damage to neutrophils in glutathione synthetase deficiency. $\mathrm{Br}$. J. Haematol. 42: 215-223.

47. Mayrargue-Kojda, A., S. Bouchilloux, and S. Lissitzky. 1958. Action d'une peroxydase végétale sur divers amino-acides phénoliques: tyrosine, thyronine, et cer- tains de leurs dérivés iodés ou hydroxylés. Bull. Soc. Chim. Biol. 40: 815-831.

48. Björkstén, F. 1966. The peroxidase-catalyzed oxidation of thyroxine. Acta Chem. Scand. 20: 1438-1439.

49. Pittman, C. S., and J. B. Chambers, Jr. 1969. Carbon structure of thyroxine metabolites in urine. Endocrinology. 84: 705-710.

50. Dratman, M. B., M. E. Richter, and H. A. Lynch. 1970. Incorporation of thyroxine carbon in protein fractions of Rana catesbiana tadpole nervous system, liver, and tail. Endocrinology. 86: 217-224.

51. Balsam, A., M. I. Surks, and S. H. Ingbar. 1980. Demonstration of in vivo ether-link cleavage of thyroxine to yield diiodotyrosine. Clin. Res. 28: 255a. (Abstr.)

52. Klebanoff, S. J. 1968. Myeloperoxidase-halide-hydrogen peroxide antibacterial system. J. Bacteriol. 95: 21312138.

53. Klebanoff, S. J. 1967. Iodination of bacteria. a bactericidal mechanism. J. Exp. Med. 126: 1063-1076. 